\title{
Source attribution of Arctic black carbon constrained by aircraft and surface measurements
}

\author{
Jun-Wei Xu ${ }^{1}$, Randall V. Martin ${ }^{1,2}$, Andrew Morrow ${ }^{1}$, Sangeeta Sharma ${ }^{3}$, Lin Huang ${ }^{3}$, W. Richard Leaitch ${ }^{3}$, \\ Julia Burkart ${ }^{4}$, Hannes Schulz ${ }^{5}$, Marco Zanatta ${ }^{5}$, Megan D. Willis ${ }^{4}$, Daven K. Henze ${ }^{6}$, Colin J. Lee ${ }^{1}$, \\ Andreas B. Herber ${ }^{5}$, and Jonathan P. D. Abbatt ${ }^{4}$ \\ ${ }^{1}$ Department of Physics and Atmospheric Science, Dalhousie University, Halifax, NS, Canada \\ ${ }^{2}$ Harvard-Smithsonian Center for Astrophysics, Cambridge, MA, USA \\ ${ }^{3}$ Atmospheric Science and Technology Directorate/Science and Technology Branch, Environment and Climate Change \\ Canada, Toronto, ON, Canada \\ ${ }^{4}$ Department of Chemistry, University of Toronto, Toronto, ON, Canada \\ ${ }^{5}$ Alfred Wegener Institute, Helmholtz Centre for Polar and Marine Research, Bremerhaven, Germany \\ ${ }^{6}$ Department of Mechanical Engineering, University of Colorado, Boulder, CO, USA
}

Correspondence to: Jun-Wei Xu (junwei.xu@dal.ca)

Received: 13 March 2017 - Discussion started: 16 March 2017

Revised: 1 September 2017 - Accepted: 6 September 2017 - Published: 10 October 2017

\begin{abstract}
Black carbon (BC) contributes to Arctic warming, yet sources of Arctic BC and their geographic contributions remain uncertain. We interpret a series of recent airborne (NETCARE 2015; PAMARCMiP 2009 and 2011 campaigns) and ground-based measurements (at Alert, Barrow and Ny-Ålesund) from multiple methods (thermal, laser incandescence and light absorption) with the GEOS-Chem global chemical transport model and its adjoint to attribute the sources of Arctic BC. This is the first comparison with a chemical transport model of refractory BC (rBC) measurements at Alert. The springtime airborne measurements performed by the NETCARE campaign in 2015 and the PAMARCMiP campaigns in 2009 and 2011 offer BC vertical profiles extending to above $6 \mathrm{~km}$ across the Arctic and include profiles above Arctic ground monitoring stations. Our simulations with the addition of seasonally varying domestic heating and of gas flaring emissions are consistent with ground-based measurements of $\mathrm{BC}$ concentrations at Alert and Barrow in winter and spring (rRMSE $<13 \%)$ and with airborne measurements of the BC vertical profile across the Arctic (rRMSE $=17 \%$ ) except for an underestimation in the middle troposphere $(500-700 \mathrm{hPa})$.

Sensitivity simulations suggest that anthropogenic emissions in eastern and southern Asia have the largest effect on the Arctic BC column burden both in spring (56\%) and annu-
\end{abstract}

ally $(37 \%)$, with the largest contribution in the middle troposphere (400-700 hPa). Anthropogenic emissions from northern Asia contribute considerable BC (27\% in spring and $43 \%$ annually) to the lower troposphere (below $900 \mathrm{hPa}$ ). Biomass burning contributes $20 \%$ to the Arctic BC column annually.

At the Arctic surface, anthropogenic emissions from northern Asia (40-45\%) and eastern and southern Asia (20$40 \%$ ) are the largest $\mathrm{BC}$ contributors in winter and spring, followed by Europe (16-36\%). Biomass burning from North America is the most important contributor to all stations in summer, especially at Barrow.

Our adjoint simulations indicate pronounced spatial heterogeneity in the contribution of emissions to the Arctic BC column concentrations, with noteworthy contributions from emissions in eastern China $(15 \%)$ and western Siberia $(6.5 \%)$. Although uncertain, gas flaring emissions from oilfields in western Siberia could have a striking impact (13\%) on Arctic BC loadings in January, comparable to the total influence of continental Europe and North America $6.5 \%$ each in January). Emissions from as far as the Indo-Gangetic Plain could have a substantial influence (6.3\% annually) on Arctic BC as well. 


\section{Introduction}

The Arctic has warmed rapidly over the last few decades at a rate about twice the global mean (AMAP, 2011; AMAP, 2015). By directly absorbing solar radiation, black carbon (BC) contributes substantially to the warming, impacting the Arctic in multiple ways (Flanner et al., 2007; Ramanathan and Carmichael, 2008; Shindell and Faluvegi, 2009; Bond et al., 2013; Sand et al., 2016). Near-surface $(<1 \mathrm{~km})$ BC particles over a highly reflective surface (i.e. snow and ice in the Arctic) warm the atmosphere and subsequently the surface (Shaw and Stamnes, 1980; Quinn et al., 2008). BC particles well above the surface warm the layer in which they reside and increase the stability of the Arctic atmosphere (e.g. Brock et al., 2011). Deposition of BC onto snow and ice can reduce surface albedo and enhance light absorption by snow and ice (Wiscombe and Warren, 1980; Chýlek et al., 1983) and trigger chain reactions involving the acceleration of snow aging (Clarke and Noone, 1985; Hansen and Nazarenko, 2004), leading to accelerated melting (Quinn et al., 2008; Namazi et al., 2015). The modified local radiative balance exerted by deposited $\mathrm{BC}$ has the potential to further affect climate at a larger scale (Flanner et al., 2007; Doherty et al., 2010).

Analyses of observations have revealed that Arctic BC is primarily transported from regions outside the Arctic (Klonecki et al., 2003; Stohl, 2006). In winter, northern Eurasia is the primary source where air masses are cold enough to penetrate the polar dome into the Arctic lower troposphere (Stohl, 2006). Air masses from the relatively warm mid-latitudes (i.e. North America and Asia) are forced to ascend above the polar dome to the Arctic middle and upper troposphere (Law and Stohl, 2007). In spring, the warming of the surface leads to higher potential temperature over the Arctic and the northward retreat of the polar dome, facilitating the transport of air masses from mid-latitude regions to the Arctic (Stohl, 2006). However, large uncertainties remain in sources and geographical contributions to Arctic BC that require additional interpretation of observations to address.

Elevated BC concentrations in the Arctic especially in winter and spring have been observed over the past few decades (Delene and Ogren, 2002; Sharma et al., 2006; Eleftheriadis et al., 2009; Yttri et al., 2014). Some studies attributed the surface BC primarily to emissions in highlatitude regions including Europe and northern Eurasia (e.g. Stohl, 2006; Shindel et al., 2008; Hirdman et al., 2010; Wang et al., 2014) while others found eastern and southern Asia had the largest contribution (Koch and Hansen, 2005; Ikeda et al., 2017). Some studies suggested that Europe was the dominant source of BC aloft (Stohl, 2006; Huang et al., 2010b) while others found eastern and southern Asia was the most important source (Sharma et al., 2013; Breider et al., 2014; Wang et al., 2014; Ikeda et al., 2017) in the middle troposphere. Recent work by Stohl et al. (2013) and Sand et al. (2016) raised questions about prior studies by identifying the im- portance of seasonally varying residential heating and by suggesting a significant overlooked source from gas flaring in high-latitude regions. In addition to anthropogenic emissions, biomass burning is another important source of Arctic BC (Stohl et al., 2007; Warneke et al., 2009; Yttri et al., 2014; Evangeliou et al., 2016), yet its contribution remains uncertain. Furthermore, evidence is emerging that the BC observations to which many prior modelling studies compared may have been biased by $30 \%$ (Sinha et al., 2017) or a factor of 2 (Sharma et al., 2017) due to other absorbing components in the atmospheric aerosol. Additional attention is needed to these issues.

$\mathrm{BC}$ emissions in mid- and low-latitude regions increase the Arctic climate forcing efficiency by altering the $\mathrm{BC}$ vertical distribution (Breider et al., 2017). Thus it is also crucial to quantify the source contributions to the vertical distribution of Arctic BC. However, vertical profiles in the Arctic have been scarce (Jacob et al., 2010; Brock et al., 2011) and anomalously influenced by biomass burning (Warneke et al., 2009). The NETCARE (Network on Climate and Aerosols: Addressing Key Uncertainties in Remote Canadian Environments; http://www.netcare-project.ca) aircraft campaign in 2015 and the PAMARCMiP (Polar Airborne Measurements and Arctic Regional Climate Model Simulation Project) aircraft campaigns in 2009 and 2011 offer a new dataset of BC measurements across the Arctic.

Source attributions of pollution in the Arctic are commonly estimated by back-trajectory analysis (Huang et al., 2010a; Harrigan et al., 2011; Barrett et al., 2015; Liu et al., 2015) and by sensitivity simulations using chemical transport models (Fisher et al., 2010; Sharma et al., 2013; Mungall et al., 2015; Evangeliou et al., 2016). These traditional approaches have been insightful but suffer from coarse regional estimates of the source location. The adjoint of a global chemical transport model (Henze et al., 2007) efficiently determines the spatially resolved source contribution to receptor locations by calculating the gradient of a cost function (e.g. Arctic column BC concentrations) with respect to the perturbations of the initial conditions (e.g. emissions). This approach has been successfully applied to quantify source contributions to Arctic surface BC in April 2008 (Qi et al., 2017b). We extend the application of this method to investigate the seasonal and annual responses of Arctic column BC to changes in regional emissions.

In this study, we first evaluate the BC concentrations simulated with the GEOS-Chem global chemical transport model with surface and aircraft measurements in the Arctic to assess the quality of different emission representations. Then sensitivity simulations are conducted to assess the regional contributions to the observed $\mathrm{BC}$ in the Arctic. We subsequently use the adjoint of the GEOS-Chem model to investigate the spatially resolved sensitivity of Arctic BC column concentrations to global emissions. Our work builds on knowledge gained from previous GEOS-Chem studies of Arctic BC (Wang et al., 2011; Breider et al., 2014, 2017; Qi 
et al., 2017a, b) with major improvements, including (1) new airborne measurements during 2009, 2011 and 2015 when more typical fires than in previous studies foster better understanding of anthropogenic source contributions to the Arctic; (2) new refractory $\mathrm{BC}$ ( $\mathrm{rBC}$ ) measurements in the Arctic more accurately constrain emissions in simulations; (3) more recent and improved emissions better represent the global redistribution of BC emissions and include flaring and seasonal emissions of residential heating; and (4) seasonal source attribution using the adjoint of GEOS-Chem reveals the importance of specific sources.

\section{Method}

\subsection{Surface measurements of $\mathrm{BC}$ in the Arctic}

Surface BC mass concentrations are measured at three Arctic stations: Alert (Nunavut, Canada; $62.3^{\circ} \mathrm{W}, 82.5^{\circ} \mathrm{N}$ ), Barrow (Alaska, USA; $156.6^{\circ} \mathrm{W}, 71.3^{\circ} \mathrm{N}$ ) and $\mathrm{Ny}$ - $\mathrm{Alesund}$ (Svalbard, Norway; $\left.11.9^{\circ} \mathrm{E}, 78.9^{\circ} \mathrm{N}\right)$. Station locations are shown in Fig. 1. Following the recommendations of Petzold et al. (2013), measurements of BC based on light absorption are here referred to as equivalent $\mathrm{BC}(\mathrm{EBC})$, measurements based on a laser-induced incandescence technique (e.g. single particle soot photometer; SP2) are referred to as rBC, and measurements based on a thermal volatilization in an oxygen-enriched environment are referred to as elemental carbon (EC).

EBC mass concentrations derived from an AE-31 Aethalometer (Magee Scientific Inc.) at Alert for 20112013 are obtained from Environment and Climate Change Canada and those at Barrow for 2010-2014 and Ny-Ålesund for 2009-2010 are obtained from the EMEP (European Monitoring and Evaluation Programme) and WDCA (World Data Centre for Aerosols) database (http://ebas.nilu.no/). The Aethalometer measures the absorption of light at $880 \mathrm{~nm}$ transmitted through particles that accumulate on a quartz fiber filter and relates the change of light absorption to light absorption coefficients $\left(\sigma_{\text {ap }}\right)$ using Beer's law. EBC mass concentrations are derived from $\sigma_{\mathrm{ap}}$ by adopting a mass absorption cross section (MAC) of $16.6 \mathrm{~m}^{2} \mathrm{~g}^{-1}$ at all stations. This MAC value is recommended by the manufacturer for Model AE31 at $880 \mathrm{~nm}$ to account for absorption by BC and additional light scattering by both particles and filter fibers.

EBC mass concentrations are also derived from a particle soot absorption photometer (PSAP, Radiance Inc.) that operates on a similar principle to the Aethalometer at the three stations. PSAP measures the absorption of light at $530 \mathrm{~nm}$. $\sigma_{\text {ap }}$ data at Alert for 2011-2013 are obtained from Environment and Climate Change Canada, and $\sigma_{\text {ap }}$ data at Barrow for 2009-2015 and Ny-Ålesund for 2009-2014 are obtained from the EMEP and WDCA database (http://ebas.nilu. no/). $\sigma_{\text {ap }}$ has been corrected for scattering following Bond et al. (1999) and is further reduced by $30 \%$ at all stations following Sinha et al. (2017). $\sigma_{\text {ap }}$ values less than the detection limit $\left(0.2 \mathrm{Mm}^{-1}\right)$ are excluded. Recent evidence is emerging that the MAC is lower than the traditional value of $10 \mathrm{~m}^{2} \mathrm{~g}^{-1}$, with recent effective MAC values ranging from $8 \mathrm{~m}^{2} \mathrm{~g}^{-1}$ (Sharma et al., 2017) to $8.7 \mathrm{~m}^{2} \mathrm{~g}^{-1}$ (Sinha et al., 2017). We adopt the average of these two values $\left(8.4 \mathrm{~m}^{2} \mathrm{~g}^{-1}\right)$ for application to PSAP measurements at all three sites.

Two additional measurements of $\mathrm{BC}$ mass concentrations are available at Alert for 2011-2013: rBC and EC. rBC is measured via laser-induced incandescence by an SP2 instrument (Droplet Measurement Technologies Inc., Boulder, $\mathrm{CO}$ ). The SP2 uses a high-intensity laser (Ni:YAG) operating at $1064 \mathrm{~nm}$ wavelength to selectively heat individual particles up to $4000 \mathrm{~K}$. At such high temperature, the non-refractory components evaporate and $\mathrm{rBC}$ mass is proportional to the intensity of the emitted incandescent light. The incandescence signal is calibrated using Aquadag particles of known size selected with a differential mobility analyzer (Sharma et al., 2017). The detection range of the SP2 at Alert spans approximately between 75 and $530 \mathrm{~nm}$ volume-equivalent diameter (Sharma et al., 2017), assuming an rBC density of $1.8 \mathrm{~g} \mathrm{~cm}^{-3}$ (Bond and Bergstrom, 2006). A lognormal function fit over the range of $80-225 \mathrm{~nm}$ is applied to calculate rBC concentrations over the $40-1000 \mathrm{~nm}$ size range that increases the rBC concentrations by about $50 \%$ (Sharma et al., 2017).

EC measurements at Alert are inferred from weeklyintegrated samples of particles collected on quartz filters with a $1 \mu \mathrm{m}$ upper size cut and analyzed using an in-house thermal technique referred to as EnCan-total-900 (Huang et al., 2006). The EnCan-total-900 method has three temperature steps with different redox conditions: 550 and $870^{\circ} \mathrm{C}$ under pure helium and $900^{\circ} \mathrm{C}$ under helium $+10 \%$ oxygen. The retention times are $600 \mathrm{~s}$ at $550^{\circ} \mathrm{C}$ for organic carbon (OC), $600 \mathrm{~s}$ at $870^{\circ} \mathrm{C}$ for pyrolysis of $\mathrm{OC}$ and carbonate carbon and $420 \mathrm{~s}$ at $900^{\circ} \mathrm{C}$ for $\mathrm{EC}$. The $870^{\circ} \mathrm{C}$ pure helium step releases pyrolysis $\mathrm{OC}$ and carbonate carbon to minimize the effect of $\mathrm{OC}$ charring on EC.

\subsection{Aircraft measurements of $\mathrm{BC}$ in the Arctic}

Prior Arctic aircraft campaigns (i.e. ARCTAS) were strongly influenced by the unusually extensive Russian fires in 2008 (e.g. Warneke et al., 2009; Wang et al., 2011; Breider et al., 2014). This study uses new aircraft observations when fires were less pronounced over multiple years (2009, 2011 and 2015) to better understand anthropogenic source contributions. The PAMARCMiP campaigns conducted springtime surveys of sea ice thickness, aerosol and meteorological parameters along the coast of the western Arctic onboard the Alfred Wegener Institute (AWI) Polar 5 aircraft. Data from two campaigns in April 2009 (Stone et al., 2010) and 25 March-6 May 2011 (Herber et al., 2012) are used here. The NETCARE campaign in April 2015 continued and extended the PAMARCMiP campaigns observations using the 


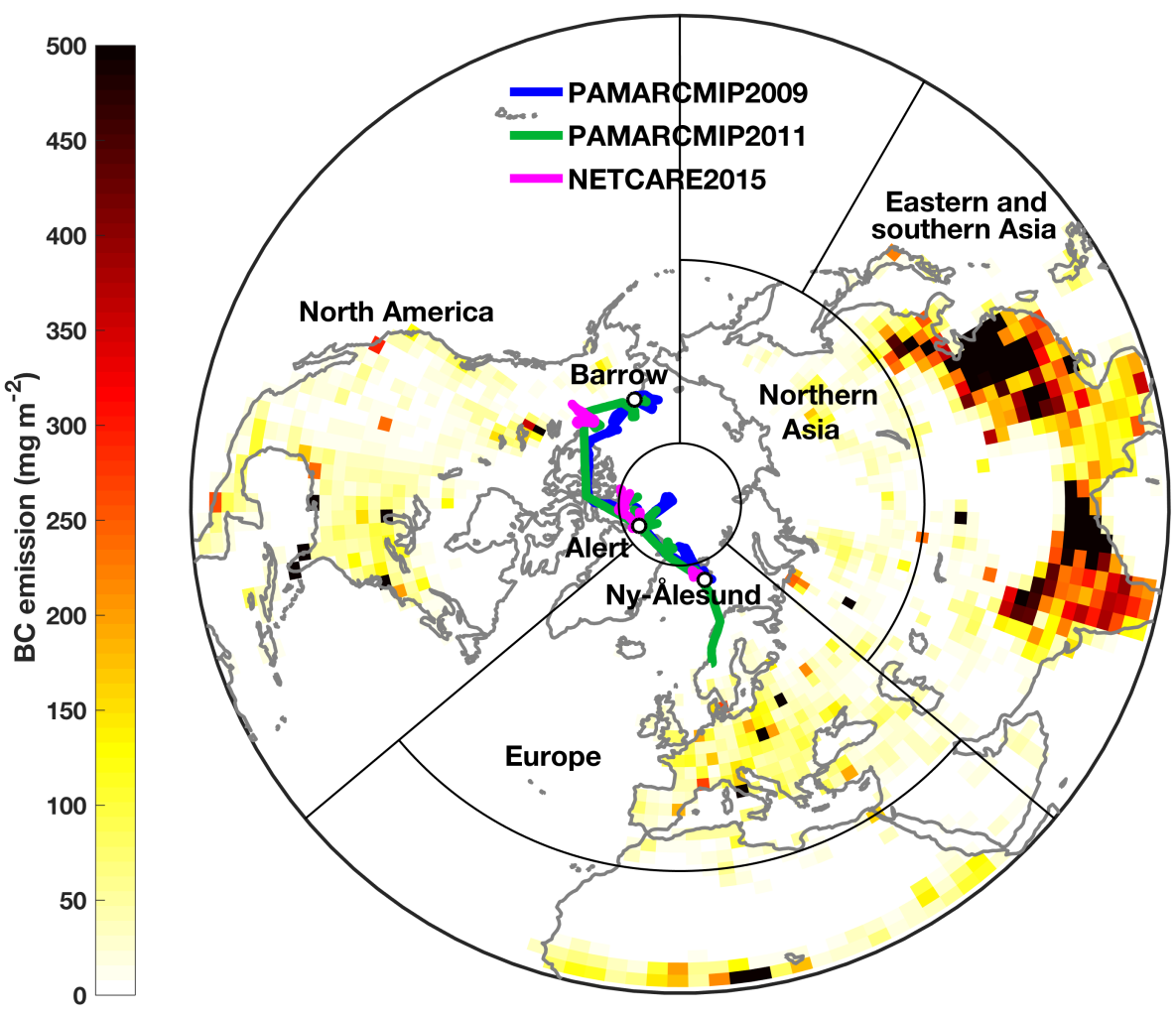

Figure 1. The colour map indicates annual total BC emissions averaged over 2009, 2011 and 2015 as used in the GEOS-Chem simulation. Black open circles indicate the locations of ground monitoring stations (Alert, Barrow and Ny-Ålesund). Coloured lines indicate the flight tracks of the NETCARE 2015 (5-21 April), the PAMARCMiP 2009 (1-25 April) and the PAMARCMiP 2011 (30 March-5 May) campaigns. Black lines outline the source regions used in this study. Regional BC emissions are in Table 1.

Polar 6 aircraft. Flight tracks of each campaign are shown in Fig. 1. All three campaigns travelled along similar routes across the western Arctic and near long-term ground monitoring stations in the Arctic (Alert, Barrow and Ny-Ålesund). Measurements of $\mathrm{rBC}$ mass concentrations during all three campaigns were performed with the state-of-the-art SP2 (Droplet Measurement Technologies Inc., Boulder, CO) instrument. The SP2 used during the PAMARCMiP campaigns was previously described in Stone et al. (2010). The NETCARE 2015 campaign used the AWI's eight-channel SP2 with a detection range of 75-700 nm of volume-equivalent diameter (assuming a particle density of $1.8 \mathrm{~g} \mathrm{~cm}^{-3}$ ) without corrections for particles outside the size range. The incandescence signal was calibrated with particles of Fullerene soot size selected with a differential mobility analyzer. The spatial and multi-year coverage of airborne measurements during these campaigns offer comprehensive representation of Arctic BC.

\subsection{Simulations of Arctic BC}

We use the GEOS-Chem global chemical transport model (version 10-01; http://geos-chem.org/) and its adjoint (ver- sion 35) to simulate Arctic BC concentrations and their sensitivities to local emissions.

Figure 1 shows the annual mean BC emissions in our GEOS-Chem simulation averaged over 2009, 2011 and 2015. We develop the simulation here to use global anthropogenic emissions of BC from version 2 of the HTAP (Hemispheric Transport of Air Pollution; http://www.htap.org/) emission inventory for 2010 (Gilardoni et al., 2011; JanssensMaenhout et al., 2015) with regional overwrites over the United States (NEI 2011) for the most recent year (2011). Global and regional BC emissions remain largely constant after 2010 (Crippa et al., 2016). The HTAP inventory is a compilation of different official emission inventories from MICS-Asia, EPA-US/Canada and TNO-Europe data, gapfilled with global emission data of EDGARv4.1. The HTAP contains BC emissions from all major sectors, including energy and industrial production, transport and residential combustion.

Table 1 contains the annual regional $\mathrm{BC}$ emissions used in the simulation. Total BC emissions from eastern and southern Asia exceed by more than a factor of 4 the $\mathrm{BC}$ emissions from either North America or Europe.

Figure 2 shows annual HTAP BC emissions and its seasonal variation over the Arctic and the Northern Hemisphere. 
Table 1. Regional annual BC emissions averaged over 2009, 2011 and 2015 as used in the GEOS-Chem simulations ${ }^{\mathrm{a}}$.

\begin{tabular}{lrrrr}
\hline $\begin{array}{l}\text { Emission source } \\
\left(\mathrm{Tg} \mathrm{C} \mathrm{yr}^{-1}\right)\end{array}$ & North America & Europe & Northern Asia & $\begin{array}{r}\text { Eastern and southern } \\
\text { Asia }\end{array}$ \\
\hline Anthropogenic & & & 0.11 & 3.36 \\
Biomass burning & 0.62 & 0.48 & 0.13 & 0.20 \\
\hline
\end{tabular}

${ }^{a}$ Regions are outlined in Fig. 1. ${ }^{\text {b }}$ Including gas flaring, fossil fuel combustion and biofuel combustion.

The Bond et al. (2007) emission inventory for 2000 is included for comparison, since it has been widely used in modelling studies of Arctic BC (Shindell et al., 2008; Koch et al., 2009; Liu et al., 2011; Wang et al., 2011; Breider et al., 2014; Qi et al., 2017a, b). The Bond et al. (2007) inventory is based on energy consumption in 1996 and contains similar emission sectors as in the HTAP. The HTAP annual emissions over the Northern Hemisphere exceed those in Bond et al. (2007) by $30 \%$, with a substantial difference in China and India where HTAP emissions are double those of Bond et al. (2007). A considerable increase of global energy consumption since 2001 especially in China and India contributes to the difference (Zhang et al., 2009; Li et al., 2017). Both inventories have low BC emissions within the Arctic. Figure 2 also shows the seasonal variation of HTAP emissions that are high in winter and spring and low in summer over the Northern Hemisphere, owing to the seasonal variation of emissions from residential heating in the HTAP. Bond et al. (2007) emissions are non-seasonal.

We also include additional $\mathrm{BC}$ emissions from gas flaring in the oil and gas industry taken from version 5 of the ECLIPSE (Evaluating the climate and Air Quality Impacts of short-Lived Pollutants) emission inventory (Klimont et al., 2016; http://eclipse.nilu.no). Gas flaring emissions of BC are calculated based on gas flaring volumes developed within the Global Gas Flaring Reduction initiative (Elvidge et al., 2007, 2011) with emission factors derived on the basis of particulate matter and soot estimates from CAPP (2007), Johnson et al. (2011) and US EPA (1995). Despite the small percentage $(\sim 5 \%)$ of flaring in total anthropogenic $\mathrm{BC}$ emissions over the Northern Hemisphere, flaring from Russia alone accounts for $93 \%$ of total anthropogenic BC emissions within the Arctic in the ECLIPSE inventory.

Emissions from biomass burning are calculated from the GFED4 (Global Fire Emissions Database version 4) inventory (Giglio et al., 2013). The GFED4 combines satellite information on fire activity and vegetation productivity to estimate globally gridded monthly burned area (including small fires) and fire emissions. We use emissions for 2009, 2011 and 2014 (the most recent year available) for the simulations of 2009, 2011 and 2015. The mismatch of emission year is unlikely to strongly influence the simulation as no abnormal fire activities were reported for 2014 and 2015. Biomass burning emissions are injected into the boundary layer in our simulations.
As discussed in Sect. 2.1, measurements of BC depend on the analysis method. However, it is ambiguous what analysis method is used to derive $\mathrm{BC}$ emission factors or $\mathrm{BC}$ speciation factors in particulate matter in various emission inventories (Bond et al., 2013). Therefore, we directly compare simulated $\mathrm{BC}$ concentrations with the best estimate of measured atmospheric BC.

The simulation of $\mathrm{BC}$ in GEOS-Chem is initially described in Park et al. (2003). BC emitted from all primary sources is in hydrophobic and hydrophilic states with a constant conversion time of one day. Dry deposition of $\mathrm{BC}$ aerosols adopts a standard resistance-in-series scheme as described in Zhang (2001) with improvements on BC dry deposition velocity over snow and ice following Fisher et al. (2010) and Wang et al. (2011). Wet deposition of BC aerosols is initially described in Liu et al. (2001) and developed by Wang et al. (2011) to distinguish between liquid cloud $(T>268 \mathrm{~K})$ in which $100 \%$ hydrophilic BC is removed and ice cloud $(T<268 \mathrm{~K})$ in which only hydrophobic BC is removed. The scavenging developments of Wang et al. (2014) are not implemented since they have little effect on Arctic BC.

Our GEOS-Chem simulations are driven by ModernEra Retrospective Analysis for Research and Applications (MERRA) meteorological fields from the NASA Global Modeling and Assimilation Office (GMAO) at $2^{\circ} \times 2.5^{\circ}$ spatial resolution with 47 vertical levels from the surface to $0.01 \mathrm{hPa}$. We conduct the simulations with a $10 \mathrm{~min}$ operator duration for transport and a $20 \mathrm{~min}$ operator duration for chemistry as recommended by Philip et al. (2016). The model is initialized with a 6-month spin-up before each simulation to remove the effects of initial conditions on aerosol simulations. The time period simulated is 2009 , 2011 and 2015, which is coincident with aircraft measurements when fires were more typical than for previous evaluations of GEOS-Chem vs. Arctic observations (i.e. Wang et al., 2011; Breider et al., 2014) to better understand anthropogenic source contributions here.

We conduct sensitivity simulations using the GEOS-Chem model to quantify the contributions of regional emissions to Arctic (hereafter refer to the region north of $66.5^{\circ} \mathrm{N}$ ) BC concentrations by excluding the regional anthropogenic source. Regions are North America $\left(180^{\circ} \mathrm{W}-50^{\circ} \mathrm{W}, 0^{\circ} \mathrm{N}-80^{\circ} \mathrm{N}\right)$, Europe $\left(50^{\circ} \mathrm{W}-50^{\circ} \mathrm{E}, 30^{\circ} \mathrm{N}-80^{\circ} \mathrm{N}\right)$, eastern and southern Asia $\left(50^{\circ} \mathrm{E}-150^{\circ} \mathrm{E}, 0^{\circ} \mathrm{N}-50^{\circ} \mathrm{N}\right)$ and northern Asia $\left(50^{\circ} \mathrm{E}-\right.$ 

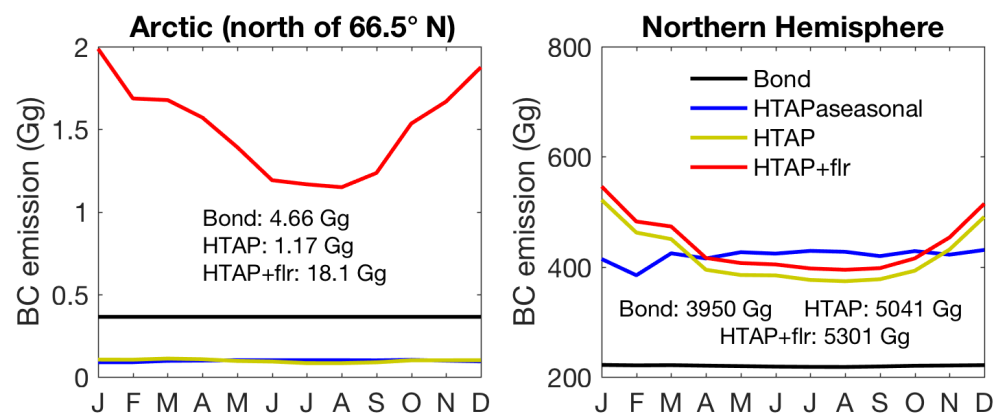

Figure 2. Anthropogenic BC emissions. Lines indicate monthly anthropogenic BC emissions from the Bond et al. (2007) non-seasonal inventory for 2000, the HTAP inventory for 2010, the HTAP inventory with non-seasonal emissions from residential heating, and the HTAP with additional flaring emissions for 2010. Annual values are given in the text.

$180^{\circ} \mathrm{E}, 50^{\circ} \mathrm{N}-80^{\circ} \mathrm{N}$ ), as outlined in Fig. 1 . We also conduct sensitivity simulations to quantify the contribution of biomass burning from North America and from the rest of the world to Arctic BC concentrations. These simulations are initialized with a 6-month spin-up as well.

We also apply the GEOS-Chem adjoint model to quantify the spatially resolved sensitivity of Arctic BC column concentrations to local emissions. A detailed description of the adjoint model is given in Henze et al. (2007). Here we briefly describe the concept in the context of our study. The adjoint model offers a computationally efficient approach to calculate the sensitivity of a model output scalar, the cost function, to a set of model input parameters such as emissions. In this study, we define the cost function as the column concentrations of $\mathrm{BC}$ north of $66.5^{\circ} \mathrm{N}$. The adjoint model calculates the partial derivatives of this cost function with respect to the modelled atmospheric state in each model grid box at each time step. This calculation is performed iteratively backward in time through transport toward emissions to yield the sensitivity of the cost function with respect to emissions.

Our adjoint simulation is driven by GEOS-5 meteorology at $2^{\circ} \times 2.5^{\circ}$ spatial resolution with 47 vertical levels from the surface to $0.01 \mathrm{hPa}$ for 2011. Differences between MERRA meteorological fields that are used in the forward model and GEOS-5 meteorological fields that are used in the adjoint are negligible $\left(r^{2}=0.99\right.$ for Arctic column BC concentrations for 2011) in the simulation of BC. Although the adjoint simulation is based on an earlier version (v8) of the GEOSChem model than the forward model version (v10-01) used in this study, the differences in BC concentrations at Arctic stations that are simulated with the adjoint and with the forward model are within $15 \%$ (Qi et al., 2017b).

\subsection{Statistics}

To assist with the evaluation of simulations, we define root mean square error (RMSE) and relative root mean square er- ror (rRMSE) as

$$
\begin{aligned}
\mathrm{RMSE} & =\sqrt{\frac{1}{N} \sum_{i=1}^{N}\left(C_{m}(i)-C_{o}(i)\right)^{2},} \\
\mathrm{rRMSE} & =100 \% \times \frac{\mathrm{RMSE}}{\frac{1}{N} \sum_{i=1}^{N} C_{m}(i)},
\end{aligned}
$$

where $C_{m}(i)$ is the model simulated concentration and $C_{o}(i)$ is the measurement concentration. $N$ is the number of measurements.

\section{Results}

\subsection{Evaluation of GEOS-Chem simulated BC concentrations in the Arctic}

Figure 3 shows the seasonal variation of $\mathrm{BC}$ concentrations from measurements and simulations at the Alert, Barrow and Ny-Ålesund stations. Different black line types indicate different instruments. Slight differences exist in sampling periods from different instruments. Restricting measurements to common years changes monthly means by less than $13 \%$, except for a $40 \%$ change at $\mathrm{Ny}-\mathrm{A} l e s u n d$ in April that arises from limited data coverage in common years since PSAP measurements for April are not available at $\mathrm{Ny}$-Ålesund in 2009. At Alert, a diversity of instruments offers valuable insight into the suite of $\mathrm{BC}$ measurements throughout the Arctic and perspective on previous model comparison with only one instrument type. EBC concentrations measured by the Aethalometer are biased high by a factor of 2 relative to $\mathrm{rBC}$ measurements due to the presence of absorbing substances other than BC (e.g. brown carbon and mineral dust), extinction issues associated with the filter matrix and uncertainties in MAC values (Sharma et al., 2017). EC concentrations are lower than EBC concentrations from the Aethalometer, yet still high relative to $\mathrm{rBC}$ partly due to the presence of pyrolysis OC and carbonate carbon (Sharma et al., 2017). 
PSAP EBC concentrations are close to the average of EC and $\mathrm{rBC}$ concentrations throughout the year. At Barrow, EBC concentrations from the Aethalometer are higher than those from the PSAP, especially in summer when the Aethalometer shows a pronounced increase in concentrations to around $55 \mathrm{ng} \mathrm{m}^{-3}$, whereas PSAP measurements reach a minimum for the year of $10 \mathrm{ng} \mathrm{m}^{-3}$. The summer peak is also observed in Aethalometer EBC measurements at $370 \mathrm{~nm}$ that is sensitive to brown carbon, indicating the influence of biomass burning. Unintentional exclusion of biomass burning plumes in the local pollution data screening performed for PSAP measurements at Barrow could contribute to the bias between the PSAP and the Aethalometer there (Stohl et al., 2006).

Following Sharma et al. (2017), we treat the best estimate of measured BC surface concentrations at Alert as the average of $\mathrm{rBC}$ and $\mathrm{EC}$ measurements, as shown by the thick black line with squares in Fig. 3. Since the PSAP EBC concentrations are close to the average of $\mathrm{rBC}$ and EC measurements throughout the year at Alert, we adopt the PSAP EBC measurements as the best estimate of surface BC at Barrow and Ny-Ålesund. The seasonal variations of surface BC at the three sites show similar features, characterized by higher concentrations in winter and early spring than in summer. At Ny-Ålesund, peak months are March and April, slightly later than at the other sites (January and February). BC concentrations at $\mathrm{Ny}-\mathrm{A} l e s u n d$ are generally lower than those at the other sites.

The surface $\mathrm{BC}$ concentrations from measurements are used to constrain emissions in the simulations. Table 2 summarizes the RMSE and rRMSE between measurements and different simulations. The green line in Fig. 3 shows simulated surface $\mathrm{BC}$ concentrations using anthropogenic emissions of BC from the Bond et al. (2007) non-seasonal emission inventory. Stohl et al. (2013) found that accounting for $\mathrm{BC}$ emissions from gas flaring and from seasonal variation of residential heating improved their simulation with a particle dispersion model (FLEXPART) during winter and early spring. Our simulation at Alert and Barrow in winter and spring is also improved by using the HTAP emissions that include seasonal variation of residential heating and by adding flaring emissions to the HTAP inventory, decreasing the bias by about a factor of 2 and reducing the rRMSE to $5.6 \%$ at Alert and $13 \%$ at Barrow. At Barrow all simulations show a distinct peak in July, which is partly due to the timing of biomass burning. Eckhardt et al. (2015) similarly observed enhanced concentrations in July at Barrow in three models (DEHM, CESM1-CAM5 and ECHAM6-HAM2) driven with the GFED3 inventory for biomass burning emissions. At NyÅlesund, all simulations overestimate measured concentrations for most of the year, potentially indicating insufficient wet deposition from riming in mixed phase clouds that occurs more frequently at this site (Qi et al., 2017a).

Figure 4 shows vertical profiles of $\mathrm{BC}$ concentrations at Alert and Ny-Ålesund averaged from the NETCARE 2015, the PAMARCMiP 2009 and the PAMARCMiP 2011 cam- paigns, along with the best estimate of ground-based measurements of April BC concentrations averaged over 2009 and 2011. Barrow is not included here due to limited number of airborne measurements (a total of 12 measurements at all pressures). The measured profile at Alert exhibits layered structure with enhanced concentrations in the middle troposphere that are attributable to a plume on 8 April 2015 around $660-760 \mathrm{hPa}$ with a peak concentration of $128 \mathrm{ng} \mathrm{m}^{-3}$. The mean ground-based measurements of $\mathrm{BC}$ concentrations at Alert are higher than airborne measurements at the same pressure by $\sim 10 \mathrm{ng} \mathrm{m}^{-3}$. Including only rBC measurements in ground-based mean concentrations reduces the difference with airborne $\mathrm{rBC}$ measurements to less than $5 \mathrm{ng} \mathrm{m}^{-3}$. At Ny-Ålesund, the measured vertical profile exhibits a zigzag shape that arises from averaging multiple years each with individual features. The mean April ground-based concentration $\left(20 \mathrm{ng} \mathrm{m}^{-3}\right)$ is about half that of the airborne measurements $\left(37 \mathrm{ng} \mathrm{m}^{-3}\right)$ at the same pressure.

Figure 5 shows spring vertical distributions of BC averaged over all points along the flight tracks of the three campaigns in Fig. 1 for measurements and simulations. Simulated vertical profiles of BC are coincidently sampled with airborne measurements for spring 2009, 2011 and 2015 and are averaged to the GEOS-Chem vertical resolution. The measured $\mathrm{rBC}$ concentrations remain roughly constant $(\sim$ $38 \mathrm{ng} \mathrm{m}^{-3}$ ) from the surface to $700 \mathrm{hPa}$, followed by an enhancement to around $50 \mathrm{ng} \mathrm{m}^{-3}$ between 700 and $500 \mathrm{hPa}$ and then a rapid decrease with altitude. This vertical distribution is similar to the measurements of the ARCTAS aircraft campaign in the Arctic in spring 2008 (Wang et al., 2011), though the magnitude of concentrations in this work is lower by a factor of about 2, likely because the Arctic was substantially influenced by strong biomass burning in northern Eurasia during the ARCTAS in spring 2008 (Warneke et al., 2009). All simulations generally represent the near-constant vertical distribution of $\mathrm{BC}$ measurements from the surface to $700 \mathrm{hPa}$ and the decrease above $500 \mathrm{hPa}$, yet none represent the enhancement between 700 and $500 \mathrm{hPa}$. Despite the comparable distributions, the magnitudes of concentrations simulated with different emissions vary substantially. Their consistency with airborne measurements is summarized in Table 2.

Figure 5 shows that the apparent bias of $40 \%$ rRMSE (17 $\left.\mathrm{ng} \mathrm{m}^{-3} \mathrm{RMSE}\right)$ in simulated concentrations with the Bond et al. (2007) non-seasonal inventory is reduced to $27 \%$ rRMSE (11 $\mathrm{ng} \mathrm{m}^{-3}$ RMSE) by the HTAP inventory with non-seasonal residential heating. The improvement is larger aloft than near-surface, indicating that the increased BC emissions in Asia in the HTAP inventory (discussed in Sect. 2) substantially contributes to the improvement. The bias vs. measurements is further reduced to $23 \% \mathrm{rRMSE}$ (9.4 $\mathrm{ng} \mathrm{m}^{-3}$ RMSE) by the HTAP emissions with seasonal residential heating, with larger improvement below $600 \mathrm{hPa}$. Adding flaring emissions further improves the consistency (17\% rRMSE; $7.2 \mathrm{ng} \mathrm{m}^{-3} \mathrm{RMSE}$ ) with measurements at all 


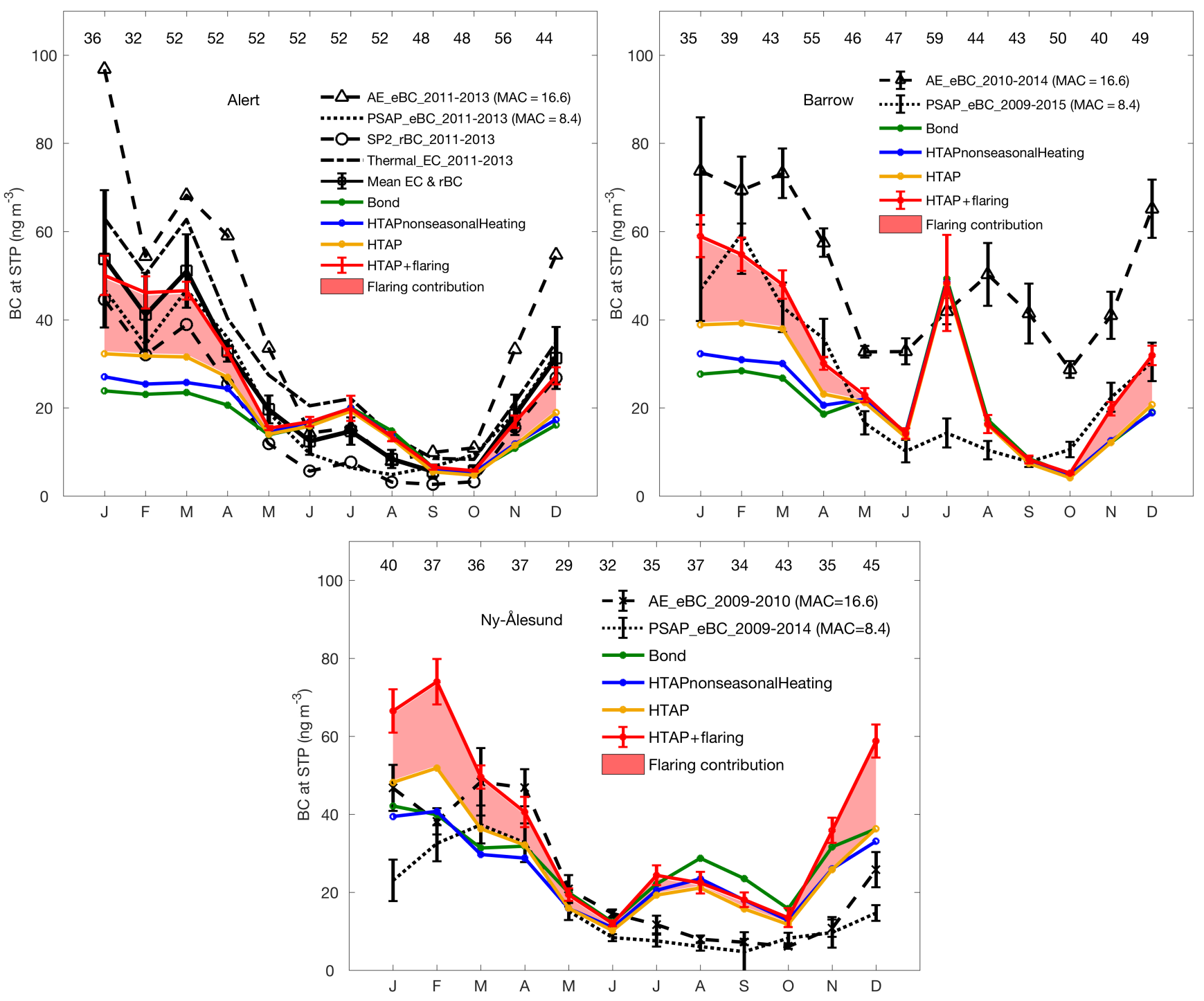

Figure 3. Seasonal variation of surface BC concentrations from measurements and simulations at selected Arctic stations. Black lines represent measurements from different instruments according to the legend. Error bars represent standard errors. The thick black line with squares at Alert is the average of $\mathrm{rBC}$ and EC concentrations. Error bars on the thick black line denote standard errors of monthly mean BC concentrations across instruments that are included in the calculation. Red shadings are the contributions from flaring to BC concentrations. Numbers below the top $x$ axis denote the total number of weekly observations from all available instruments in each month. Simulated monthly BC concentrations are the monthly averages of simulated concentrations for 2009, 2011 and 2015. Simulations use different emission inventories that are represented in colour according to the legend. Error bars on the simulation represent standard errors. Concentrations from measurements and simulations are all calculated at standard temperature and pressure (STP).

levels with larger effects in the lower troposphere, especially near the surface where the RMSE is only $3.2 \mathrm{ng} \mathrm{m}^{-3}$. The substantial portion $(93 \%)$ of flaring in $\mathrm{BC}$ emissions within the Arctic (Fig. 2) explains the larger effect near the ground. The remaining underestimation of $14 \mathrm{ng} \mathrm{m}^{-3}$ RMSE in 500$700 \mathrm{hPa}$ in the HTAP + flaring simulation is possibly due to insufficient emissions or preferential sampling of plumes by the aircraft as discussed further below. If the measurements are representative in this region, the Arctic $\mathrm{BC}$ burden below
$500 \mathrm{hPa}$ in springtime could be $6.5 \%$ larger than simulated here.

Figure $6 \mathrm{a}$ and $\mathrm{b}$ show the spatial distribution of $\mathrm{BC}$ concentrations from aircraft measurements gridded onto the GEOS-Chem grid along with that from the HTAP + flaring simulation. The simulation represents well the spatial distribution of BC measurements, with concentrations of 30 $70 \mathrm{ng} \mathrm{m}^{-3}$ near Barrow and $\mathrm{Ny}-\AA \AA^{2} l e s u n d$ and lower concentrations of $20-40 \mathrm{ng} \mathrm{m}^{-3}$ near Alert, yet the simulation underestimates concentrations at three hotspots (labelled as 
Table 2. Summary of root mean square error (RMSE) and relative root mean square error (rRMSE) between simulations with different emissions and measurements for BC surface concentrations at Arctic stations (in reference to Fig. 3) and for vertical concentrations from airborne measurements (in reference to Fig. 5).

\begin{tabular}{lrrrr}
\hline RMSE $\left(\mathrm{ng} \mathrm{m}^{-3} ;\right.$ rRMSE) & Alert & Barrow & Ny-Ålesund & Vertical \\
\hline Bond $^{\mathrm{a}}$ & $13(55 \%)$ & $17(66 \%)$ & $15(88 \%)$ & $17(40 \%)$ \\
HTAPnonseasonalheating $^{\mathrm{b}}$ & $11(48 \%)$ & $16(61 \%)$ & $12(71 \%)$ & $11(27 \%)$ \\
HTAPheating $^{\mathrm{c}}$ & $8.7(37 \%)$ & $13(52 \%)$ & $14(82 \%)$ & $9.4(23 \%)$ \\
HTAPheatingflaring $^{\mathrm{d}}$ & $3.7(16 \%)$ & $11(44 \%)$ & $25(150 \%)$ & $7.2(17 \%)$ \\
\hline
\end{tabular}

a Bond et al. (2007) emission inventory for 2000. ${ }^{\mathrm{b}}$ HTAP v2 inventory for 2010 with non-seasonal residential heating. ${ }^{\mathrm{c}}$ HTAP v2 inventory for 2010 with seasonal residential heating. ${ }^{\mathrm{d}}$ HTAP v2 inventory for 2010 with seasonal residential heating and the addition of flaring emissions from the ECLIPSE v5 inventory.
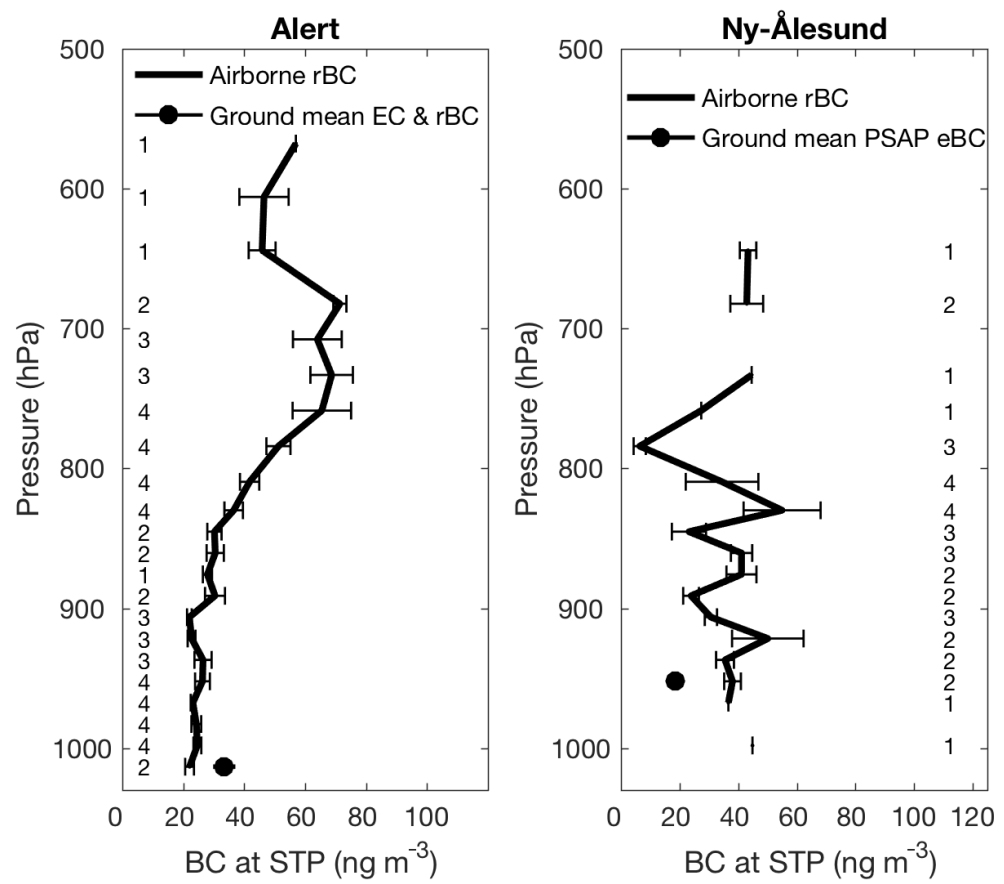

Figure 4. Vertical profile of $\mathrm{BC}$ concentrations averaged from all points along the flight tracks of the three aircraft campaigns (NETCARE 2015, the PAMARCMiP 2009 and the PAMARCMiP 2011) in Alert and Ny-Ålesund areas, along with the best estimate of April BC concentrations from ground-based measurements averaged for 2009 and 2011 . The Alert area is defined as $59^{\circ} \mathrm{W}-65^{\circ} \mathrm{W}, 81.3^{\circ} \mathrm{N}-83.4^{\circ} \mathrm{N}$ and the $\mathrm{Ny}$-Ålesund area is within $12^{\circ} \mathrm{E}-18^{\circ} \mathrm{E}, 77.8^{\circ} \mathrm{N}-79.1^{\circ} \mathrm{N}$. Numbers along the $y$ axis are the number of airborne measurements in each pressure bin. All concentrations are presented at STP. Error bars on ground measurements are standard errors.

$\mathrm{a}, \mathrm{b}, \mathrm{c})$. Hotspot a is near Barrow along the coast of the Beaufort Sea and is affected by a plume around $800 \mathrm{hPa}$ on 6 April 2011 and a plume around $500 \mathrm{hPa}$ on 20 April 2015. Hotspot $b$ is west of the Baffin Bay in Nunavut and is affected by a plume near $800 \mathrm{hPa}$ on 10 April 2011. Hotspot c is near Ny-Ålesund and is caused by a plume at around $700 \mathrm{hPa}$ on 5 May 2011. The underestimated magnitudes of these plumes, likely related to emissions or numerical diffusion, may contribute to the underestimation of BC concentrations between 500 and $700 \mathrm{hPa}$ in Fig. 5. Figure 6c shows mean simulated BC concentrations between 500 and $700 \mathrm{hPa}$ in April. Concentrations are highest $\left(\sim 70 \mathrm{ng} \mathrm{m}^{-3}\right)$ in northeastern Russia and near Barrow, with a gradual decrease east- ward to around $50 \mathrm{ng} \mathrm{m}^{-3}$ near Alert to reach the lowest concentrations of below $40 \mathrm{ng} \mathrm{m}^{-3}$ in the southern Arctic near Ny-Ålesund. This gradient illustrates the overall sources and transport pathways affecting $\mathrm{BC}$ in the Arctic middle troposphere in springtime. The following section will investigate the enhanced concentrations in northeastern Russia and their relation to sources in eastern and southern Asia.

Figure 6d-f show pan-Arctic spatial distributions of BC column (1000-300 hPa) concentrations from the HTAP + flaring simulation for January, April and July. Strong spatial and seasonal variation is observed in $\mathrm{BC}$ columns with the highest overall concentrations in April and in the eastern Arctic. Emissions remain similar for the 


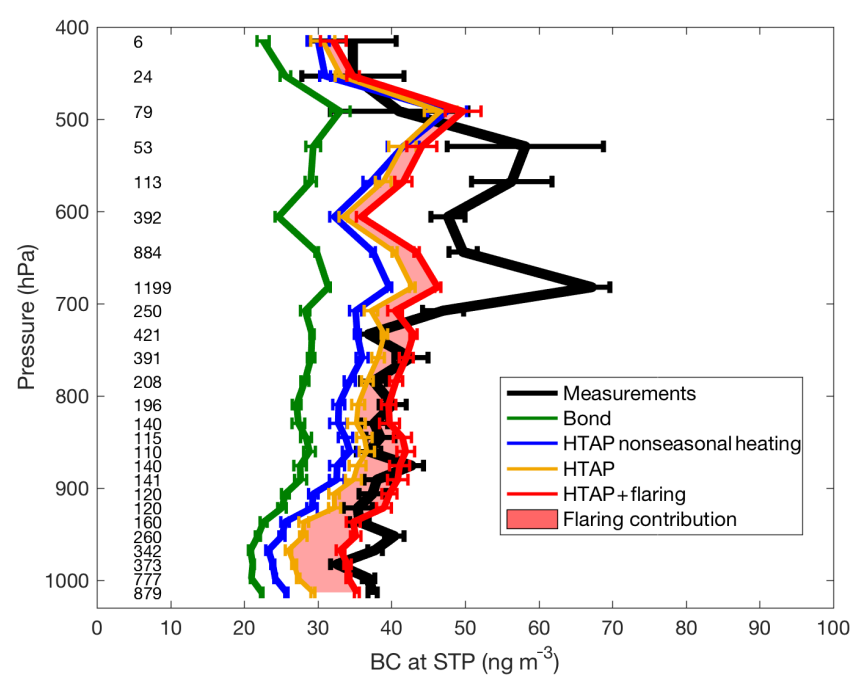

Figure 5. Mean spring vertical profiles of BC concentrations from measurements and simulations averaged over $50 \mathrm{hPa}$ pressure bins from all points along the flight tracks of the NETCARE 2015, the PAMARCMiP 2009 and the PAMARCMiP 2011 campaigns. The red shading denotes the contribution of flaring to BC concentrations. Simulated vertical profiles of BC are coincidently sampled with airborne measurements for spring 2009, 2011 and 2015 and are averaged to the GEOS-Chem vertical resolution. Simulations include different emission inventories that are represented in different lines according to the legend. Error bars are standard errors. Numbers along the $y$ axis represent the number of measurements in each pressure bin. All concentrations are presented at STP.

3 months as shown in Fig. $6 \mathrm{~g}-\mathrm{i}$, indicating that the main reason for the seasonal variation of Arctic BC column is transport efficiency. In July, the enhanced concentrations in western Siberia due to flaring are less obvious due to more effective wet scavenging in summer. North America exhibits remarkably high BC column in July (Fig. 6f) from biomass burning as will be discussed further in Sect. 3.2.

Since BC concentrations simulated with HTAP + flaring exhibit overall consistency with the measured seasonal variation and the measured spatial distributions, we use this inventory in the following simulations for source attributions.

\subsection{Source attribution of $\mathrm{BC}$ in the Arctic}

Figure 7a shows the contribution of anthropogenic emissions from regions defined in Fig. 1, as well as that of biomass burning from North America and the rest of the world, to springtime airborne $\mathrm{BC}$ along the flight tracks of the three aircraft campaigns in Fig. 1. Contributions are quantified by excluding regional emissions. At all levels, anthropogenic emissions explain more than $90 \%$ of BC concentrations, of which $56 \%$ is contributed by eastern and southern Asia, followed by Europe with a contribution of $19 \%$. Biomass burning is minor $(\sim 8 \%)$ compared to anthropogenic emissions in the contribution to springtime Arctic BC loadings, and the biomass burning impact on the springtime Arctic almost exclusively originates from regions other than North America. The relative contribution of anthropogenic emissions from each source region varies with altitude, partly reflecting different transport pathways and scavenging efficiencies. The influence of eastern and southern Asia increases considerably with altitude, with a contribution of $66 \%$ between 400 and $700 \mathrm{hPa}$ and $46 \%$ between 900 and $1000 \mathrm{hPa}$, because transport from mid-latitudes follows isentropic surfaces that slope upward toward the middle or upper troposphere in the Arctic (Klonecki et al., 2003). In contrast, the influence of northern Asia decreases rapidly with altitude by a factor of 10 from the surface to $400-700 \mathrm{hPa}$, reflecting transport from sufficiently cold regions along the low-level isentropic surfaces into the Arctic and direct transport within the polar dome (Klonecki et al., 2003; Stohl, 2006). The impact of Europe is roughly uniform throughout the troposphere, suggesting both of the above pathways are possible.

The gas flaring contribution to the springtime vertical BC concentration is shown as the red shading in Fig. 5. The contribution decreases with altitude from $\sim 20 \%$ near the surface to $<10 \%$ above $800 \mathrm{hPa}$ because flaring occurs almost exclusively below $2 \mathrm{~km}$ a.s.l. (Stohl et al., 2013) and because the high-latitude sources of flaring limit isentropic lifting in the polar dome (Stohl, 2006).

Figure $7 \mathrm{~b}$ shows the annual mean vertical contribution of anthropogenic emissions from each source region and of biomass burning to Arctic BC. Anthropogenic emissions from eastern and southern Asia $(37 \%)$ and biomass burning emissions $(25 \%)$ are major sources of Arctic tropospheric BC, along with a substantial contribution (43\%) from anthropogenic emissions in northern Asia near the surface $(900-1000 \mathrm{hPa})$. Unlike in spring, roughly half of biomass burning $\mathrm{BC}$ originates from North America in the annual attribution. Compared to springtime, the annual anthropogenic contribution from eastern and southern Asia is smaller and that from northern Asia is substantially larger in the lower troposphere. This reflects that long-range transport from eastern and southern Asia is more favourable in spring due to warm conveyor belts (Liu et al., 2015) and that proximal transport from northern Asia is more efficient in winter owing to the extended Arctic front to the south of northern Asian sources (Stohl, 2006).

The dominant role of eastern and southern Asia in the middle troposphere is consistent with Ikeda et al. (2017), who studied the source attribution of Arctic BC using a tagged tracer method in GEOS-Chem with the HTAP v2.2 emission inventory. The largest contribution from eastern and southern Asia to Arctic BC burden in this study is also consistent with Ma et al. (2013) and Wang et al. (2014). However, some prior studies suggested that Europe had the largest contribution to the Arctic BC burden (Stohl, 2006; Shindell et al., 2008; Huang et al., 2010b; Sharma et al., 2013). The difference likely arises from trends in anthropogenic emissions 

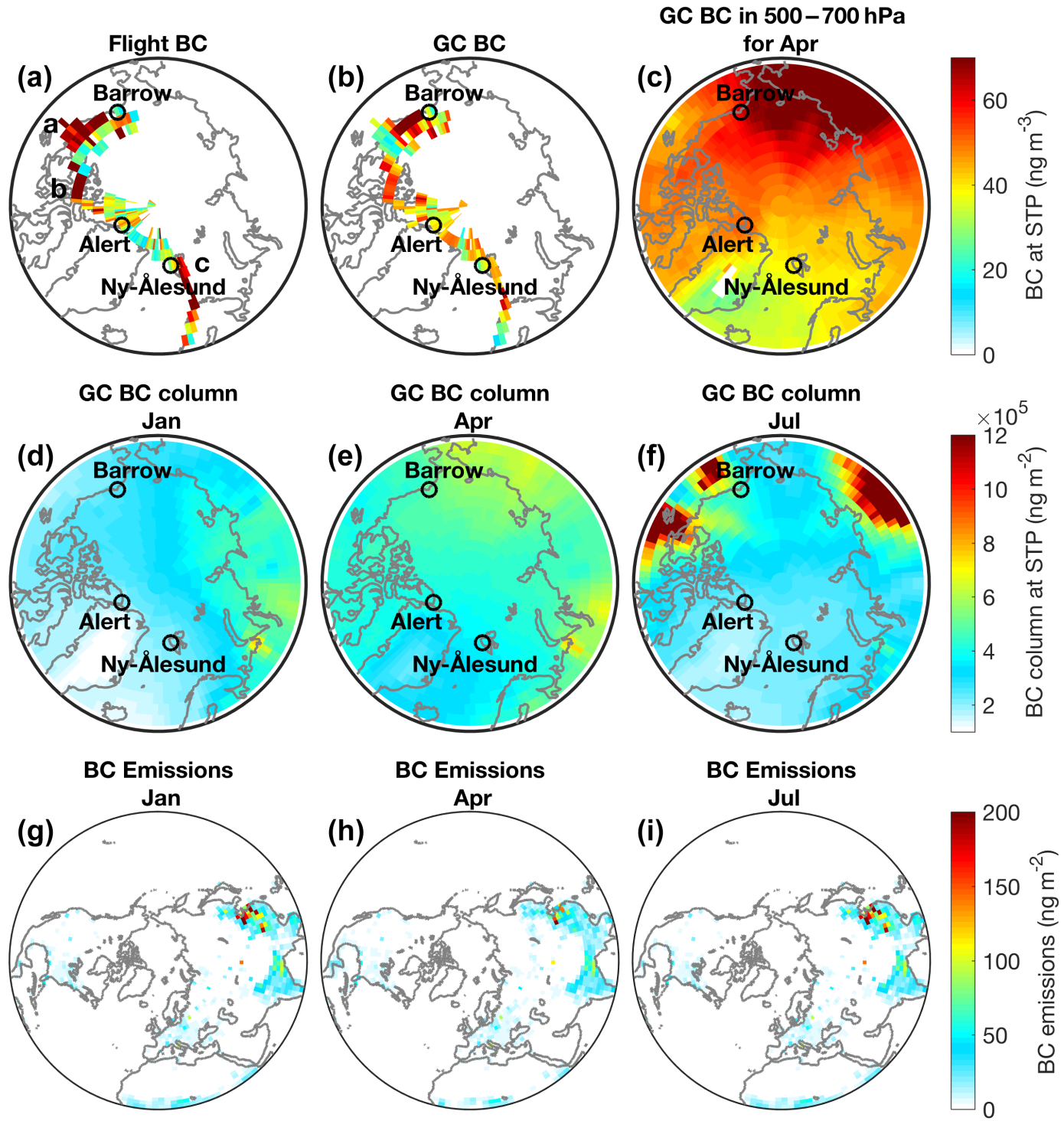

Figure 6. (a) BC concentrations from the NETCARE 2015 and PAMARCMiP 2009 and 2011 aircraft campaigns averaged on the GEOSChem grid, along with three hotspots labelled as a, b, c. (b) BC concentrations from GEOS-Chem simulations coincidently sampled with flight measurements. (c) BC concentrations between 500 and $700 \mathrm{hPa}$ simulated with the HTAP + flaring emissions in April averaged over 2009, 2011 and 2015. Circles are ground monitoring stations. (d-f) Pan-Arctic BC column concentrations simulated with the HTAP + flaring emissions for January (d), April (e) and July (f) averaged over 2009, 2011 and 2015. All concentrations are at STP. (g-i) Total BC emissions for January (g), April (h) and July (i) averaged over 2009, 2011 and 2015.

with reductions from Europe and increases in eastern and southern Asia as discussed further below.

Figure 8 shows the simulated source attribution of surface BC at Alert, Barrow and Ny-Ålesund. For all stations, anthropogenic emissions from northern Asia, eastern and southern Asia, and Europe are major contributors to high concentrations of BC in winter and early spring. In summer, anthropogenic contributions decline rapidly while biomass burning predominantly from North America becomes the primary source. At Alert and Barrow, the largest contributions are anthropogenic emissions from northern Asia in winter $(\sim 50 \%)$ and from eastern and southern Asia in spring ( $40 \%$ ). Barrow shows a pronounced peak in summer, more than $90 \%$ of which is explained by biomass burning from North America. At Ny-Ålesund, anthropogenic emissions in Europe and northern Asia are significant sources of BC in winter and early spring with a contribution of $\sim 30 \%$ from each source.

The contributions from gas flaring to surface BC concentrations are shown as the red shadings in Fig. 3. Flaring accounts for $\sim 25 \%$ of concentrations in winter and spring and less than $5 \%$ in summer at all stations except Ny-Ålesund 

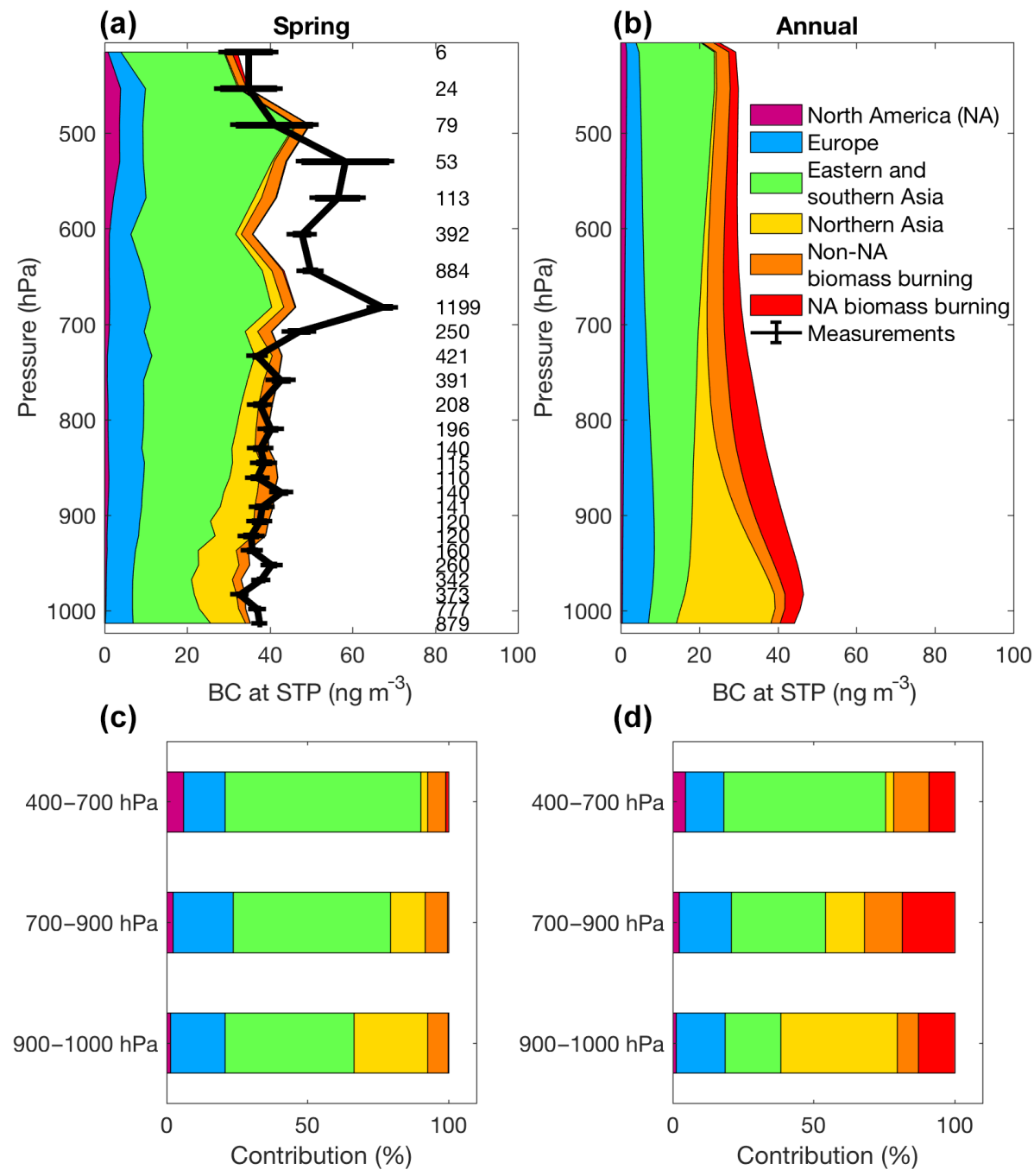

Figure 7. (a) Mean spring BC vertical profiles from flight measurements and simulations that are colour-coded to anthropogenic sources from regions defined in Fig. 1 and biomass burning sources from North America and the rest of the world. Flight measurements and error bars are the same as in Fig. 5. Simulated vertical profiles of BC are taken coincidently with flight measurements. Numbers along the $y$ axis represent the number of measurements in each pressure bin. (b) Annual mean vertical profile of BC for the entire Arctic from simulations that are colour-coded to source regions. Concentrations are all presented at STP. (c and d) Regional contributions binned by pressure.

where flaring contributes $14 \%$ of $\mathrm{BC}$ in summer. This result is consistent with Stohl et al. (2013), who studied the flaring contribution to surface $\mathrm{BC}$ concentrations at Arctic stations using the FLEXPART model.

We also investigated the influence of international shipping from the HTAP v2 inventory for 2010 on Arctic surface $\mathrm{BC}$ concentrations and found the contribution is less than $1 \%$ at all stations due to the small magnitude of emissions $(<1 \%$ of total anthropogenic BC emissions globally and within the Arctic). This source is expected to increase by $16 \%$ by 2050 (Winther et al., 2014).

Our source attribution of Arctic surface BC has consistencies with that of Koch and Hansen (2005), who investigated the origins of Arctic $\mathrm{BC}$ using a general circulation model and found that Russia, Europe and southern Asia each accounted for $20-30 \%$ of springtime surface BC. However, some studies (e.g. Stohl, 2006; Shindell et al., 2008; Gong et al., 2010; Sharma et al., 2013) suggested lower contributions $(<10 \%)$ from eastern and southern Asia and higher contributions $(>30 \%)$ from Europe than our results. The main difference is due to emission trends such that our anthropogenic BC emissions from eastern and southern Asia are generally $30 \%$ higher than those in earlier studies (e.g. Shindell et al., 2008; Sharma et al., 2013) due to rapid development since 2000 and that our anthropogenic BC emissions in Europe are half those in prior studies due to European emission controls. 


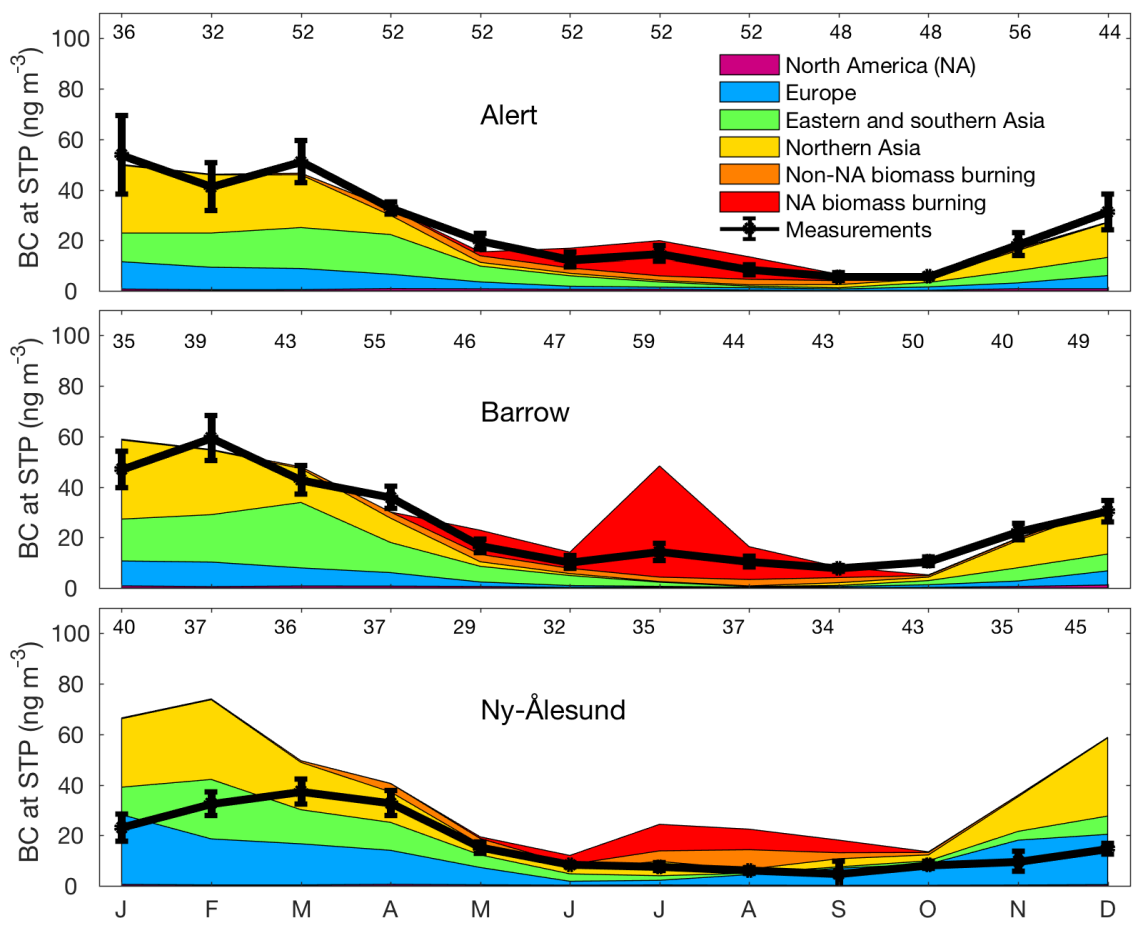

Figure 8. Monthly variation of BC surface concentrations at selected Arctic stations from measurements and simulations that are colourcoded to anthropogenic sources from regions defined in Fig. 1 and biomass burning sources from North America and the rest of the world. The measured monthly mean concentrations of $\mathrm{BC}$ and error bars are the same as the best estimate of surface $\mathrm{BC}$ concentrations in Fig. 3 . Simulated monthly concentrations are monthly averages of 2009, 2011 and 2015. Numbers below the top $x$ axis denote the total number of weekly observations from all available instruments in each month. Concentrations are all presented at STP.

Figure 9 shows the contributions to Arctic BC column concentrations from changes in local emissions in 2011 as calculated with the GEOS-Chem adjoint. Pronounced seasonal variation and spatial heterogeneity are found. Sources in January are strongly influenced by specific Asian regions including western Siberia, eastern China and the Indo-Gangetic Plain, whereas sources in other seasons are more widespread across Europe and North America. Several hotspots are found in each season. In January, oilfields in western Siberia have a total impact of $13 \%$ on Arctic BC loadings, of which $4.4 \%$ is from the Timan-Pechora basin oilfield and $6.4 \%$ from the West Siberia oilfields, suggesting that the influence of western Siberia is comparable to the total influence of continental Europe and North America $(\sim 6.5 \%$ each in January). Considerable flaring emissions (67\% of total flaring emissions north of $60^{\circ} \mathrm{N}$ in January) and close proximity to the Arctic contribute to the substantial influence of these oilfields in western Siberia. The Indo-Gangetic Plain also exhibits considerable impact (7.2\%) to the Arctic in January, reflecting the substantial emissions there as shown in Fig. 1. In April, the influence of western Siberia decreases to $4.4 \%$ with the northward retreat of the Arctic front. In contrast, contributions from emissions in eastern China $(25 \%)$ and North America $(8.2 \%)$ are enhanced owing to the facilitated transport of air masses from warm regions (e.g. the US and
Asia) in spring (Klonecki et al., 2003). Emission contributions to Arctic BC loadings are generally weak in July, but the Tarim oilfield in western China stands out as the second most influential (3.2\%) grid cell to the Arctic, which is comparable to the influence of half of continental Europe $(6 \%)$. The Tarim oilfield is located in a high-altitude $(\sim 1000 \mathrm{~m})$ arid region (Taklamakan Desert). Considerable flaring emissions, less-efficient wet scavenging and elevation all facilitate its large contribution to the Arctic. The contribution from North America is the largest (13\%) in July, consistent with the remarkably high BC loadings over high-latitude North America as shown in Fig. 6f. Annually, eastern China (15\%), western Siberia $(6.5 \%)$ and the Indo-Gangetic Plain $(6.3 \%)$ have the largest impact on Arctic BC loadings, along with a noteworthy contribution from the Tarim oilfield (2.6\%). At continental scales, eastern and southern Asia contributes $40 \%$ to the Arctic BC loadings. Northern Asia, North America and Europe each make a contribution of $\sim 10 \%$, consistent with the vertical source attribution from sensitivity simulations in Fig. 7b. BC emissions within the Arctic generally contribute less than $3 \%$ of Arctic BC loadings in all seasons except for January $(5 \%)$. 


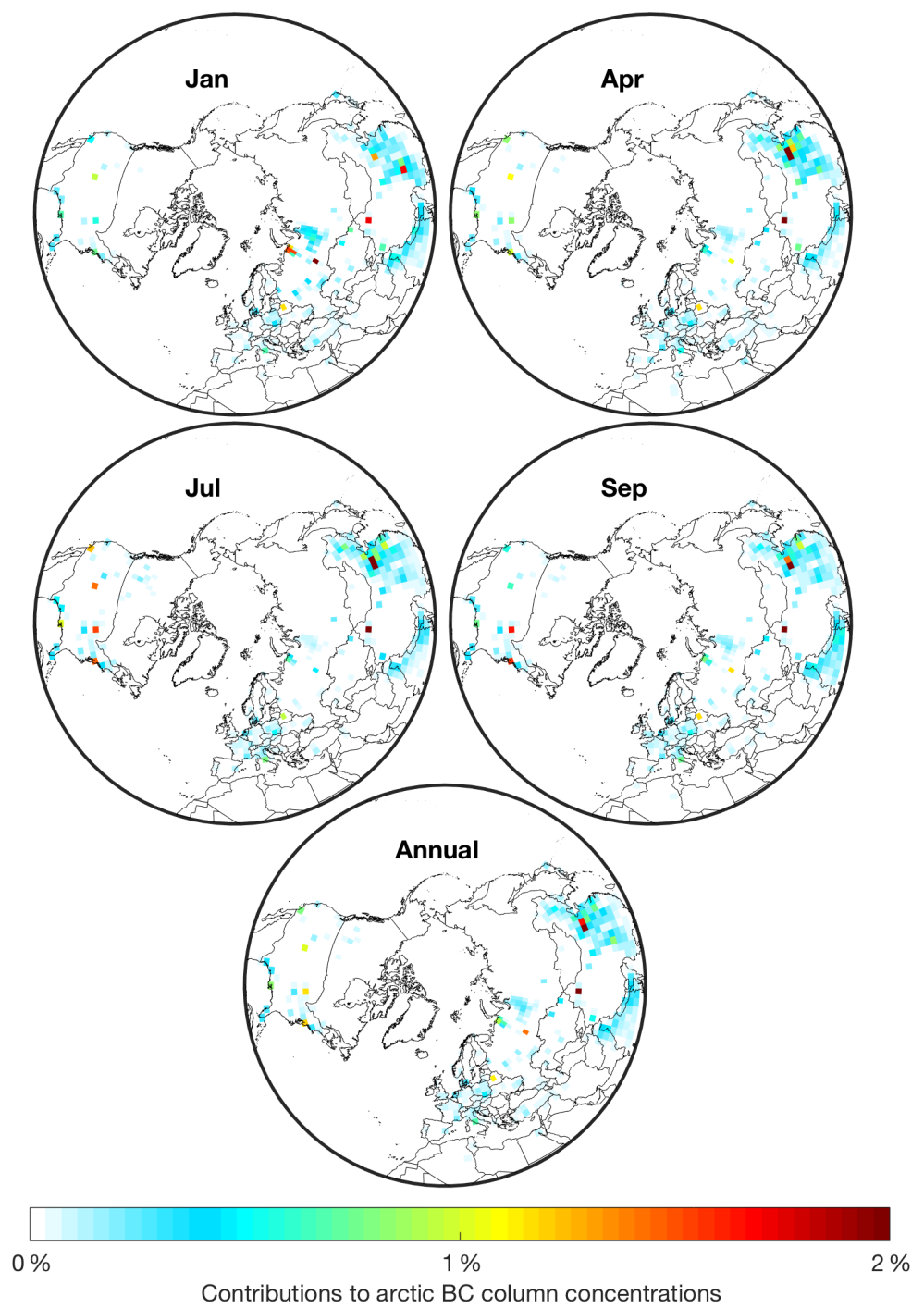

Figure 9. Contributions to Arctic BC column concentrations from changes in local emissions (as percent change in Arctic BC column concentration per fractional change in emissions) in 2011. Local emissions include anthropogenic and biomass burning emissions. The annual map is the average of contributions in January, April, July and September calculated with the adjoint model.

\section{Conclusions}

Airborne measurements of $\mathrm{BC}$ concentrations taken across the Arctic during the NETCARE 2015, the PAMARCMiP 2009 and the PAMARCMiP 2011 campaigns, along with long-term ground-based measurements of $\mathrm{BC}$ concentrations from three Arctic stations (Alert, Barrow and Ny-Ålesund), were interpreted with the GEOS-Chem chemical transport model and its adjoint to quantify the sources of Arctic BC. Measurements from multiple BC instruments (rBC, EC, EBC) were examined to quantify Arctic $\mathrm{BC}$ concentrations. We relied on $\mathrm{rBC}$ and $\mathrm{EC}$ measurements and on EBC inferred from PSAP absorption measurements with a MAC calibrated to $\mathrm{rBC}$ and EC measurements. The new rBC measurements at Alert differed by up to a factor of 2 from commonly used measurements as discussed by Sharma et al. (2017) and played a major role in our ability to simulate observations at Alert. Our simulations with the addition of seasonally varying domestic heating and of gas flaring emissions were consistent with ground-based measurements of the $\mathrm{BC}$ concentrations at Alert and Barrow in winter and spring (rRMSE $<$ $13 \%$ ) and represented airborne measurements of $\mathrm{BC}$ vertical profile across the Arctic (rRMSE $=17 \%$ ), yet underestimated an enhancement of BC concentrations between 500 and $700 \mathrm{hPa}$ that was affected by several plumes near Alert, Barrow and Ny-Ålesund. The weaker biomass burning influences on the airborne measurements used here than in prior ARCTAS and ARCPAC campaigns facilitated our interpretation for anthropogenic source attribution. 
Sensitivity simulations with the GEOS-Chem model were conducted to assess the contribution of geographic sources to Arctic BC. The Arctic tropospheric BC burden was predominantly affected by anthropogenic emissions from eastern and southern Asia (56\% in spring and $37 \%$ annually from 1000 to $400 \mathrm{hPa}$ ) with larger contributions aloft (66\% in spring and $57 \%$ annually between 40 and $700 \mathrm{hPa}$ ) than near the surface (46\% in spring and $20 \%$ annually below $900 \mathrm{hPa}$ ), reflecting long-range transport in the middle troposphere. Anthropogenic emissions from northern Asia had considerable contributions in the lower troposphere $(27 \%$ in spring and $43 \%$ annually below $900 \mathrm{hPa}$ ) due to low-level proximal transport. Biomass burning contributed $25 \%$ to the annual BC burden.

Surface BC was largely influenced by anthropogenic emissions from northern Asia ( $>50 \%$ ) in winter and eastern and southern Asia in spring $(\sim 40 \%)$ at both Alert and Barrow and from Europe $(\sim 30 \%)$ and northern Asia $(\sim 30 \%)$ at Ny-Ålesund in winter and early spring. Biomass burning, primarily from North America, was the most important contributor to surface BC at all stations in summer, especially at Barrow.

Our adjoint simulations indicated pronounced spatial and seasonal heterogeneity in the contribution of emissions to Arctic BC column concentrations. Eastern China (15\%) and western Siberia $(6.5 \%)$ had a noteworthy influence on Arctic BC loadings on an annual average. Emissions from as far south as the Indo-Gangetic Plain also had a considerable influence $(6.3 \%)$ on the Arctic annually. The Tarim oilfield stood out as the second-most influential grid cell with an annual contribution of $2.6 \%$. Gas flaring emissions from oilfields in western Siberia had a striking impact $(13 \%)$ on the Arctic BC burden in January, which was comparable to the total impact of continental Europe and North America (6.5\% each in January).

The increasing BC fraction from eastern and southern Asia at higher altitudes could have significant implications for Arctic warming by extending the trend in increasing $\mathrm{BC}$ radiative forcing efficiency found by Breider et al. (2017) driven by strong increase with altitude of the direct radiative forcing of BC (Zarzycki and Bond, 2010; Samset and Myhre, 2015). Furthermore, anthropogenic emissions of BC in southern Asia are projected to increase under several IPCC scenarios (Streets et al., 2004; Bond et al., 2013). The climate implications of $\mathrm{BC}$ emissions within the Arctic are concerning given their disproportionate warming effects and the potential for increasing Arctic shipping activity as ice cover declines (Sand et al., 2013). The considerable impact of emissions from China and Indo-Gangetic Plain on the Arctic deserves further investigation. Additional work to reconcile the different $\mathrm{BC}$ mass concentrations measured by different instruments would be valuable to reduce uncertainties in BC studies not only in the Arctic but also globally.
Data availability. The data used in this study are available from the corresponding author upon request (junwei.xu@dal.ca).

Competing interests. The authors declare that they have no conflict of interest.

Special issue statement. This article is part of the special issues "Global and regional assessment of intercontinental transport of air pollution: results from HTAP, AQMEII and MICS" and "NETCARE (Network on Aerosols and Climate: Addressing Key Uncertainties in Remote Canadian Environments) (ACP/AMT/BG interjournal SI)". It does not belong to a conference.

Acknowledgements. The authors acknowledge the financial support provided for NETCARE through the Climate Change and Atmospheric Research Program at NSERC Canada. We also acknowledge the World Data Centre for Aerosol, in which BC measurements from Arctic stations are hosted (http://ebas.nilu.no). We thank all operators at Barrow and $\mathrm{Ny}$-Ålesund stations for maintaining and providing ground-based BC measurements. We also thank the developers of the HTAP and ECLIPSE emission inventories.

Edited by: Lynn M. Russell

Reviewed by: Nikolaos Evangeliou and two anonymous referees

\section{References}

AMAP: The Impact of Black Carbon on Arctic Climate, edited by: Quinn, P. K., Stohl, A., Arneth, A., Berntsen, T., Burkhart, J. F., Christensen, J., Flanner, M., Kupiainen, K., Lihavainen, H., Shepherd, M., Shevchenko, V., Skov, H., and Vestreng, V., Arctic Monitoring and Assessment Programme (AMAP), Oslo, 72 pp., 2011.

AMAP: AMAP Assessment 2015: Black Carbon and Ozone as Arctic Climate Forcers, Arctic Monitoring and Assessment Programme (AMAP), Oslo, Norway, 2015.

Barrett, T. E., Robinson, E. M., Usenko, S., and Sheesley, R. J.: Source contributions to wintertime elemental and organic carbon in the Western Arctic based on radiocarbon and tracer apportionment, Environ. Sci. Technol., 49, 11631-11639, https://doi.org/10.1021/acs.est.5b03081, 2015.

Bond, T. C. and Bergstrom, R. W.: Light absorption by carbonaceous particles: an investigative review, Aerosol Sci. Tech., 40, 27-67, https://doi.org/10.1080/02786820500421521, 2006.

Bond, T. C., Anderson, T. L., and Campbell, D.: Calibration and intercomparison of filter-based measurements of visible light absorption by aerosols, Aerosol Sci. Tech., 30, 582-600, https://doi.org/10.1080/027868299304435, 1999.

Bond, T. C., Bhardwaj, E., Dong, R., Jogani, R., Jung, S., Roden, C., Streets, D. G., and Trautmann, N. M.: Historical emissions of black and organic carbon aerosol from energy-related combustion, 1850-2000, Global Biogeochem. Cy., 21, GB2018, https://doi.org/10.1029/2006GB002840, 2007. 
Bond, T. C., Doherty, S. J., Fahey, D. W., Forster, P. M., Berntsen, T., DeAngelo, B. J., Flanner, M. G., Ghan, S., Kärcher, B., Koch, D., Kinne, S., Kondo, Y., Quinn, P. K., Sarofim, M. C., Schultz, M. G., Schulz, M., Venkataraman, C., Zhang, H., Zhang, S., Bellouin, N., Guttikunda, S. K., Hopke, P. K., Jacobson, M. Z., Kaiser, J. W., Klimont, Z., Lohmann, U., Schwarz, J. P., Shindell, D., Storelvmo, T., Warren, S. G., and Zender, C. S.: Bounding the role of black carbon in the climate system: a scientific assessment, J. Geophys. Res.Atmos., 118, 5380-5552, https://doi.org/10.1002/jgrd.50171, 2013.

Breider, T. J., Mickley, L. J., Jacob, D. J., Wang, Q., Fisher, J. A., Chang, R. Y.-W., and Alexander, B.: Annual distributions and sources of Arctic aerosol components, aerosol optical depth, and aerosol absorption, J. Geophys. Res.-Atmos., 119, 4107-4124, https://doi.org/10.1002/2013JD020996, 2014.

Breider, T. J., Mickley, L. J., Jacob, D. J., Ge, C., Wang, J., Payer Sulprizio, M., Croft, B., Ridley, D. A., McConnell, J. R., Sharma, S., Husain, L., Dutkiewicz, V. A., Eleftheriadis, K., Skov, H., and Hopke, P. K.: Multidecadal trends in aerosol radiative forcing over the Arctic: contribution of changes in anthropogenic aerosol to Arctic warming since 1980, J. Geophys. Res.-Atmos., 122, 3573-3594, https://doi.org/10.1002/2016JD025321, 2017.

Brock, C. A., Cozic, J., Bahreini, R., Froyd, K. D., Middlebrook, A. M., McComiskey, A., Brioude, J., Cooper, O. R., Stohl, A., Aikin, K. C., de Gouw, J. A., Fahey, D. W., Ferrare, R. A., Gao, R.-S., Gore, W., Holloway, J. S., Hübler, G., Jefferson, A., Lack, D. A., Lance, S., Moore, R. H., Murphy, D. M., Nenes, A., Novelli, P. C., Nowak, J. B., Ogren, J. A., Peischl, J., Pierce, R. B., Pilewskie, P., Quinn, P. K., Ryerson, T. B., Schmidt, K. S., Schwarz, J. P., Sodemann, H., Spackman, J. R., Stark, H., Thomson, D. S., Thornberry, T., Veres, P., Watts, L. A., Warneke, C., and Wollny, A. G.: Characteristics, sources, and transport of aerosols measured in spring 2008 during the aerosol, radiation, and cloud processes affecting Arctic Climate (ARCPAC) Project, Atmos. Chem. Phys., 11, 2423 2453, https://doi.org/10.5194/acp-11-2423-2011, 2011.

CAPP: A recommended approach to completing the national pollutant release inventory (NPRI) for the upstream oil and gas industry, Canadian Association of Petroleum Producers (CAPP): http://www.capp.ca/library/publications/policyRegulatory/ pages/pubInfo.aspx?DocId=119572 (last access: 6 October 2017), 2007.

Chýlek, P., Ramaswamy, V., and Srivastava, V.: Albedo of soot-contaminated snow, J. Geophys. Res., 88, 10837, https://doi.org/10.1029/JC088iC15p10837, 1983.

Clarke, A. D. and Noone, K. J.: Soot in the Arctic snowpack: a cause for perturbations in radiative transfer, Atmos. Environ., 19, 2045-2053, https://doi.org/10.1016/0004-6981(85)90113-1, 1985.

Crippa, M., Janssens-Maenhout, G., Dentener, F., Guizzardi, D., Sindelarova, K., Muntean, M., Van Dingenen, R., and Granier, C.: Forty years of improvements in European air quality: regional policy-industry interactions with global impacts, Atmos. Chem. Phys., 16, 3825-3841, https://doi.org/10.5194/acp-163825-2016, 2016.

Delene, D. J. and Ogren, J. A.: Variability of aerosol optical properties at four North American surface monitoring sites,
J. Atmos. Sci., 59, 1135-1150, https://doi.org/10.1175/15200469(2002)059<1135:VOAOPA>2.0.CO;2, 2002.

Doherty, S. J., Warren, S. G., Grenfell, T. C., Clarke, A. D., and Brandt, R. E.: Light-absorbing impurities in Arctic snow, Atmos. Chem. Phys., 10, 11647-11680, https://doi.org/10.5194/acp-1011647-2010, 2010.

Eckhardt, S., Quennehen, B., Olivié, D. J. L., Berntsen, T. K., Cherian, R., Christensen, J. H., Collins, W., Crepinsek, S., Daskalakis, N., Flanner, M., Herber, A., Heyes, C., Hodnebrog, Ø., Huang, L., Kanakidou, M., Klimont, Z., Langner, J., Law, K. S., Lund, M. T., Mahmood, R., Massling, A., Myriokefalitakis, S., Nielsen, I. E., Nøjgaard, J. K., Quaas, J., Quinn, P. K., Raut, J.-C., Rumbold, S. T., Schulz, M., Sharma, S., Skeie, R. B., Skov, H., Uttal, T., von Salzen, K., and Stohl, A.: Current model capabilities for simulating black carbon and sulfate concentrations in the Arctic atmosphere: a multi-model evaluation using a comprehensive measurement data set, Atmos. Chem. Phys., 15, 9413-9433, https://doi.org/10.5194/acp-15-9413-2015, 2015.

Eleftheriadis, K., Vratolis, S., and Nyeki, S.: Aerosol black carbon in the European Arctic: measurements at Zeppelin station, Ny-Ålesund, Svalbard from 1998-2007, Geophys. Res. Lett., 36, L02809, https://doi.org/10.1029/2008GL035741, 2009.

Elvidge, C. D., Baugh, K. E., Tuttle, B. T., Howard, A. T., Pack, D. W., Milesi, C., and Erwin, E. H.: A twelve year record of national and global gas flaring volumes estimated using satellite data: final report to the World Bank, NOAA National Geophysical Data Center, Boulder, US, available at: http://www.ngdc. noaa.gov/dmsp/interest/gas_flares.html, 2007.

Elvidge, C. D., Baugh, K. E., Anderson, S., Ghosh, T., and Ziskin, D.: Estimation of gas flaring volumes using NASA MODIS fire detection products, NOAA National Geophysical Data Center, Boulder, US, available at: http://www.ngdc.noaa.gov/dmsp/ interest/gas_flares.html, 2011.

Evangeliou, N., Balkanski, Y., Hao, W. M., Petkov, A., Silverstein, R. P., Corley, R., Nordgren, B. L., Urbanski, S. P., Eckhardt, S., Stohl, A., Tunved, P., Crepinsek, S., Jefferson, A., Sharma, S., Nøjgaard, J. K., and Skov, H.: Wildfires in northern Eurasia affect the budget of black carbon in the Arctic - a 12 year retrospective synopsis (2002-2013), Atmos. Chem. Phys., 16, 75877604, https://doi.org/10.5194/acp-16-7587-2016, 2016.

Fisher, J. A., Jacob, D. J., Purdy, M. T., Kopacz, M., Le Sager, P., Carouge, C., Holmes, C. D., Yantosca, R. M., Batchelor, R. L., Strong, K., Diskin, G. S., Fuelberg, H. E., Holloway, J. S., Hyer, E. J., McMillan, W. W., Warner, J., Streets, D. G., Zhang, Q., Wang, Y., and Wu, S.: Source attribution and interannual variability of Arctic pollution in spring constrained by aircraft (ARCTAS, ARCPAC) and satellite (AIRS) observations of carbon monoxide, Atmos. Chem. Phys., 10, 977-996, https://doi.org/10.5194/acp-10-977-2010, 2010.

Flanner, M. G., Zender, C. S., Randerson, J. T., and Rasch, P. J.: Present-day climate forcing and response from black carbon in snow, J. Geophys. Res., 112, D11202, https://doi.org/10.1029/2006JD008003, 2007.

Giglio, L., Randerson, J. T., and van der Werf, G. R.: Analysis of daily, monthly, and annual burned area using the fourthgeneration global fire emissions database (GFED4), J. Geophys. Res. Biogeo., 118, 317-328, https://doi.org/10.1002/jgrg.20042, 2013. 
Gilardoni, S., Vignati, E., and Wilson, J.: Using measurements for evaluation of black carbon modeling, Atmos. Chem. Phys., 11, 439-455, https://doi.org/10.5194/acp-11-439-2011, 2011.

Gong, S. L., Zhao, T. L., Sharma, S., Toom-Sauntry, D., Lavoué, D., Zhang, X. B., Leaitch, W. R., and Barrie, L. A.: Identification of trends and interannual variability of sulfate and black carbon in the Canadian High Arctic: 1981-2007, J. Geophys. Res., 115, D07305, https://doi.org/10.1029/2009JD012943, 2010.

Hansen, J. and Nazarenko, L.: Soot climate forcing via snow and ice albedos, P. Natl. Acad. Sci. USA, 101, 423-428, https://doi.org/10.1073/pnas.2237157100, 2004.

Harrigan, D. L., Fuelberg, H. E., Simpson, I. J., Blake, D. R., Carmichael, G. R., and Diskin, G. S.: Anthropogenic emissions during Arctas-A: mean transport characteristics and regional case studies, Atmos. Chem. Phys., 11, 8677-8701, https://doi.org/10.5194/acp-11-8677-2011, 2011.

Henze, D. K., Hakami, A., and Seinfeld, J. H.: Development of the adjoint of GEOS-Chem, Atmos. Chem. Phys., 7, 2413-2433, https://doi.org/10.5194/acp-7-2413-2007, 2007.

Herber, A. B., Haas, C., Stone, R. S., Bottenheim, J. W., Liu, P., Li, S.-M., Staebler, R. M., Strapp, J. W., and Dethloff, K.: Regular airborne surveys of Arctic sea ice and atmosphere, Eos T. Am. Geophys. Un., 93, 41-42, https://doi.org/10.1029/2012EO040001, 2012.

Hirdman, D., Burkhart, J. F., Sodemann, H., Eckhardt, S., Jefferson, A., Quinn, P. K., Sharma, S., Ström, J., and Stohl, A.: Long-term trends of black carbon and sulphate aerosol in the Arctic: changes in atmospheric transport and source region emissions, Atmos. Chem. Phys., 10, 9351-9368, https://doi.org/10.5194/acp-109351-2010, 2010.

Huang, L., Brook, J. R., Zhang, W., Li, S. M., Graham, L., Ernst, D., Chivulescu, A., and Lu, G.: Stable isotope measurements of carbon fractions $(\mathrm{OC} / \mathrm{EC})$ in airborne particulate: a new dimension for source characterization and apportionment, Atmos. Environ., 40, 2690-2705, https://doi.org/10.1016/j.atmosenv.2005.11.062, 2006.

Huang, L., Gong, S. L., Sharma, S., Lavoué, D., and Jia, C. Q.: A trajectory analysis of atmospheric transport of black carbon aerosols to Canadian high Arctic in winter and spring (1990-2005), Atmos. Chem. Phys., 10, 5065-5073, https://doi.org/10.5194/acp-10-5065-2010, 2010a.

Huang, L., Gong, S. L., Jia, C. Q., and Lavoué, D.: Relative contributions of anthropogenic emissions to black carbon aerosol in the Arctic, J. Geophys. Res., 115, D19208, https://doi.org/10.1029/2009JD013592, 2010 b.

Ikeda, K., Tanimoto, H., Sugita, T., Akiyoshi, H., Kanaya, Y., Zhu, C., and Taketani, F.: Tagged tracer simulations of black carbon in the Arctic: transport, source contributions, and budget, Atmos. Chem. Phys., 17, 10515-10533, https://doi.org/10.5194/acp-1710515-2017, 2017

Jacob, D. J., Crawford, J. H., Maring, H., Clarke, A. D., Dibb, J. E., Emmons, L. K., Ferrare, R. A., Hostetler, C. A., Russell, P. B., Singh, H. B., Thompson, A. M., Shaw, G. E., McCauley, E., Pederson, J. R., and Fisher, J. A.: The Arctic Research of the Composition of the Troposphere from Aircraft and Satellites (ARCTAS) mission: design, execution, and first results, Atmos. Chem. Phys., 10, 5191-5212, https://doi.org/10.5194/acp10-5191-2010, 2010.
Janssens-Maenhout, G., Crippa, M., Guizzardi, D., Dentener, F., Muntean, M., Pouliot, G., Keating, T., Zhang, Q., Kurokawa, J., Wankmüller, R., Denier van der Gon, H., Kuenen, J. J. P., Klimont, Z., Frost, G., Darras, S., Koffi, B., and Li, M.: HTAP_v2.2: a mosaic of regional and global emission grid maps for 2008 and 2010 to study hemispheric transport of air pollution, Atmos. Chem. Phys., 15, 11411-11432, https://doi.org/10.5194/acp-15-11411-2015, 2015.

Johnson, M. R., Devillers, R. W., and Thomson, K. A.: Quantitative Field Measurement of Soot Emission from a Large Gas Flare Using Sky-LOSA, Environ. Sci. Technol., 45, 345-350, https://doi.org/10.1021/es102230y, 2011.

Klimont, Z., Kupiainen, K., Heyes, C., Purohit, P., Cofala, J., Rafaj, P., Borken-Kleefeld, J., and Schöpp, W.: Global anthropogenic emissions of particulate matter including black carbon, Atmos. Chem. Phys., 17, 8681-8723, https://doi.org/10.5194/acp-178681-2017, 2017.

Klonecki, A.: Seasonal changes in the transport of pollutants into the Arctic troposphere-model study, J. Geophys. Res., 108, 8367, https://doi.org/10.1029/2002JD002199, 2003.

Koch, D. and Hansen, J.: Distant origins of Arctic black carbon: a Goddard Institute for Space Studies ModelE experiment, J. Geophys. Res., 110, D04204, https://doi.org/10.1029/2004JD005296, 2005.

Koch, D., Schulz, M., Kinne, S., McNaughton, C., Spackman, J. R., Balkanski, Y., Bauer, S., Berntsen, T., Bond, T. C., Boucher, O., Chin, M., Clarke, A., De Luca, N., Dentener, F., Diehl, T., Dubovik, O., Easter, R., Fahey, D. W., Feichter, J., Fillmore, D., Freitag, S., Ghan, S., Ginoux, P., Gong, S., Horowitz, L., Iversen, T., Kirkevåg, A., Klimont, Z., Kondo, Y., Krol, M., Liu, X., Miller, R., Montanaro, V., Moteki, N., Myhre, G., Penner, J. E., Perlwitz, J., Pitari, G., Reddy, S., Sahu, L., Sakamoto, H., Schuster, G., Schwarz, J. P., Seland, Ø., Stier, P., Takegawa, N., Takemura, T., Textor, C., van Aardenne, J. A., and Zhao, Y.: Evaluation of black carbon estimations in global aerosol models, Atmos. Chem. Phys., 9, 9001-9026, https://doi.org/10.5194/acp-99001-2009, 2009.

Law, K. S. and Stohl, A.: Arctic air pollution: origins and impacts, Science, 315, 1537-1540, https://doi.org/10.1126/science.1137695, 2007.

Li, M., Zhang, Q., Kurokawa, J.-I., Woo, J.-H., He, K., Lu, Z., Ohara, T., Song, Y., Streets, D. G., Carmichael, G. R., Cheng, Y., Hong, C., Huo, H., Jiang, X., Kang, S., Liu, F., Su, H., and Zheng, B.: MIX: a mosaic Asian anthropogenic emission inventory under the international collaboration framework of the MICS-Asia and HTAP, Atmos. Chem. Phys., 17, 935-963, https://doi.org/10.5194/acp-17-935-2017, 2017.

Liu, D., Quennehen, B., Darbyshire, E., Allan, J. D., Williams, P. I., Taylor, J. W., Bauguitte, S. J.-B., Flynn, M. J., Lowe, D., Gallagher, M. W., Bower, K. N., Choularton, T. W., and Coe, H.: The importance of Asia as a source of black carbon to the European Arctic during springtime 2013, Atmos. Chem. Phys., 15, 11537 11555, https://doi.org/10.5194/acp-15-11537-2015, 2015.

Liu, H., Jacob, D. J., Bey, I., and Yantosca, R. M.: Constraints from ${ }^{210} \mathrm{~Pb}$ and ${ }^{7} \mathrm{Be}$ on wet deposition and transport in a global threedimensional chemical tracer model driven by assimilated meteorological fields, J. Geophys. Res.-Atmos., 106, 12109-12128, https://doi.org/10.1029/2000JD900839, 2001. 
Liu, J., Fan, S., Horowitz, L. W., and Levy, H.: Evaluation of factors controlling long-range transport of black carbon to the Arctic, J. Geophys. Res., 116, D04307, https://doi.org/10.1029/2010JD015145, 2011.

Ma, P.-L., Rasch, P. J., Wang, H., Zhang, K., Easter, R. C., Tilmes, S., Fast, J. D., Liu, X., Yoon, J.-H., and Lamarque, J.F.: The role of circulation features on black carbon transport into the Arctic in the Community Atmosphere Model version 5 (CAM5), J. Geophys. Res.-Atmos., 118, 4657-4669, https://doi.org/10.1002/jgrd.50411, 2013.

Mungall, E. L., Croft, B., Lizotte, M., Thomas, J. L., Murphy, J. G., Levasseur, M., Martin, R. V., Wentzell, J. J. B., Liggio, J., and Abbatt, J. P. D.: Dimethyl sulfide in the summertime Arctic atmosphere: measurements and source sensitivity simulations, Atmos. Chem. Phys., 16, 6665-6680, https://doi.org/10.5194/acp16-6665-2016, 2016.

Namazi, M., von Salzen, K., and Cole, J. N. S.: Simulation of black carbon in snow and its climate impact in the Canadian Global Climate Model, Atmos. Chem. Phys., 15, 10887-10904, https://doi.org/10.5194/acp-15-10887-2015, 2015.

Park, R. J., Jacob, D. J., Chin, M., and Martin, R. V: Sources of carbonaceous aerosols over the United States and implications for natural visibility, J. Geophys. Res.-Atmos., 108, 4355, https://doi.org/10.1029/2002JD003190, 2003.

Petzold, A., Ogren, J. A., Fiebig, M., Laj, P., Li, S.-M., Baltensperger, U., Holzer-Popp, T., Kinne, S., Pappalardo, G., Sugimoto, N., Wehrli, C., Wiedensohler, A., and Zhang, X.-Y.: Recommendations for reporting "black carbon" measurements, Atmos. Chem. Phys., 13, 8365-8379, https://doi.org/10.5194/acp13-8365-2013, 2013.

Philip, S., Martin, R. V., and Keller, C. A.: Sensitivity of chemistrytransport model simulations to the duration of chemical and transport operators: a case study with GEOS-Chem v10-01, Geosci. Model Dev., 9, 1683-1695, https://doi.org/10.5194/gmd9-1683-2016, 2016.

Qi, L., Li, Q., Li, Y., and He, C.: Factors controlling black carbon distribution in the Arctic, Atmos. Chem. Phys., 17, 1037-1059, https://doi.org/10.5194/acp-17-1037-2017, 2017a.

Qi, L., Li, Q., Henze, D. K., Tseng, H.-L., and He, C.: Sources of springtime surface black carbon in the Arctic: an adjoint analysis for April 2008, Atmos. Chem. Phys., 17, 9697-9716, https://doi.org/10.5194/acp-17-9697-2017, 2017 b.

Quinn, P. K., Bates, T. S., Baum, E., Doubleday, N., Fiore, A. M., Flanner, M., Fridlind, A., Garrett, T. J., Koch, D., Menon, S., Shindell, D., Stohl, A., and Warren, S. G.: Shortlived pollutants in the Arctic: their climate impact and possible mitigation strategies, Atmos. Chem. Phys., 8, 1723-1735, https://doi.org/10.5194/acp-8-1723-2008, 2008.

Ramanathan, V. and Carmichael, G.: Global and regional climate changes due to black carbon, Nat. Geosci., 1, 221-227, https://doi.org/10.1038/ngeo156, 2008.

Samset, B. H. and Myhre, G.: Climate response to externally mixed black carbon as a function of altitude, J. Geophys. Res.-Atmos., 120, 2913-2927, https://doi.org/10.1002/2014JD022849, 2015.

Sand, M., Berntsen, T. K., Seland, Ø., and Kristjánsson, J. E.: Arctic surface temperature change to emissions of black carbon within Arctic or midlatitudes, J. Geophys. Res.-Atmos., 118, 77887798, https://doi.org/10.1002/jgrd.50613, 2013.
Sand, M., Berntsen, T. K., von Salzen, K., Flanner, M. G., Langner, J., and Victor, D. G.: Response of Arctic temperature to changes in emissions of short-lived climate forcers, Nat. Clim. Change, 6, 286-289, 2016.

Sharma, S., Andrews, E., Barrie, L. A., Ogren, J. A., and Lavoué, D.: Variations and sources of the equivalent black carbon in the high Arctic revealed by long-term observations at Alert and Barrow: 1989-2003, J. Geophys. Res., 111, D14208, https://doi.org/10.1029/2005JD006581, 2006.

Sharma, S., Ishizawa, M., Chan, D., Lavoué, D., Andrews, E., Eleftheriadis, K., and Maksyutov, S.: 16 year simulation of Arctic black carbon: transport, source contribution, and sensitivity analysis on deposition, J. Geophys. Res.-Atmos., 118, 943-964, https://doi.org/10.1029/2012JD017774, 2013.

Sharma, S., Leaitch, W. R., Huang, L., Veber, D., Kolonjari, F., Zhang, W., Hanna, S. J., Bertram, A. K., and Ogren, J. A.: An Evaluation of three methods for measuring black carbon at Alert, Canada, Atmos. Chem. Phys. Discuss., https://doi.org/10.5194/acp-2017-339, in review, 2017.

Shaw, G. E. and Stamnes, K.: Arctic haze: perturbation of the polar radiation budget, Ann. Ny. Acad. Sci., 338, 533-539, https://doi.org/10.1111/j.1749-6632.1980.tb17145.x, 1980.

Shindell, D. and Faluvegi, G.: Climate response to regional radiative forcing during the twentieth century, Nat. Geosci., 2, 294-300, 2009.

Shindell, D. T., Chin, M., Dentener, F., Doherty, R. M., Faluvegi, G., Fiore, A. M., Hess, P., Koch, D. M., MacKenzie, I. A., Sanderson, M. G., Schultz, M. G., Schulz, M., Stevenson, D. S., Teich, H., Textor, C., Wild, O., Bergmann, D. J., Bey, I., Bian, H., Cuvelier, C., Duncan, B. N., Folberth, G., Horowitz, L. W., Jonson, J., Kaminski, J. W., Marmer, E., Park, R., Pringle, K. J., Schroeder, S., Szopa, S., Takemura, T., Zeng, G., Keating, T. J., and Zuber, A.: A multi-model assessment of pollution transport to the Arctic, Atmos. Chem. Phys., 8, 5353-5372, https://doi.org/10.5194/acp-8-5353-2008, 2008.

Sinha, P. R., Kondo, Y., Koike, M., Ogren, J. A., Jefferson, A., Barrett, T. E., Sheesley, R. J., Ohata, S., Moteki, N., Coe, H., Liu, D., Irwin, M., Tunved, P., Quinn, P. K. and Zhao, Y.: Evaluation of ground-based black carbon measurements by filter-based photometers at two Arctic sites, J. Geophys. Res.-Atmos., 122, 3544-3572, https://doi.org/10.1002/2016JD025843, 2017.

Stohl, A.: Characteristics of atmospheric transport into the Arctic troposphere, J. Geophys. Res., 111, D11306, https://doi.org/10.1029/2005JD006888, 2006.

Stohl, A., Andrews, E., Burkhart, J. F., Forster, C., Herber, A., Hoch, S. W., Kowal, D., Lunder, C., Mefford, T., Ogren, J. A., Sharma, S., Spichtinger, N., Stebel, K., Stone, R., Ström, J., Tørseth, K., Wehrli, C., and Yttri, K. E.: Pan-Arctic enhancements of light absorbing aerosol concentrations due to North American boreal forest fires during summer 2004, J. Geophys. Res., 111, D22214, https://doi.org/10.1029/2006JD007216, 2006.

Stohl, A., Berg, T., Burkhart, J. F., Fjǽraa, A. M., Forster, C., Herber, A., Hov, Ø., Lunder, C., McMillan, W. W., Oltmans, S., Shiobara, M., Simpson, D., Solberg, S., Stebel, K., Ström, J., Tørseth, K., Treffeisen, R., Virkkunen, K., and Yttri, K. E.: Arctic smoke - record high air pollution levels in the European Arctic due to agricultural fires in Eastern Europe in spring 2006, 
Atmos. Chem. Phys., 7, 511-534, https://doi.org/10.5194/acp-7511-2007, 2007.

Stohl, A., Klimont, Z., Eckhardt, S., Kupiainen, K., Shevchenko, V. P., Kopeikin, V. M., and Novigatsky, A. N.: Black carbon in the Arctic: the underestimated role of gas flaring and residential combustion emissions, Atmos. Chem. Phys., 13, 8833-8855, https://doi.org/10.5194/acp-13-8833-2013, 2013.

Stone, R. S., Herber, A., Vitale, V., Mazzola, M., Lupi, A., Schnell, R. C., Dutton, E. G., Liu, P. S. K., Li, S.-M., Dethloff, K., Lampert, A., Ritter, C., Stock, M., Neuber, R., and Maturilli, M.: A three-dimensional characterization of Arctic aerosols from airborne Sun photometer observations: PAM-ARCMIP, April 2009, J. Geophys. Res., 115, D13203, https://doi.org/10.1029/2009JD013605, 2010.

Streets, D. G., Bond, T. C., Lee, T., and Jang, C.: On the future of carbonaceous aerosol emissions, J. Geophys. Res., 109, D24212, https://doi.org/10.1029/2004JD004902, 2004.

US EPA: Compilation of Air Pollutant Emission Factors - Volume I: Stationary Point and Area Sources, AP-42 5th Edition, US Environmental Protection Agency (US EPA), Springfield, VA, 1995.

Wang, H., Rasch, P. J., Easter, R. C., Singh, B., Zhang, R., Ma, P.-L., Qian, Y., Ghan, S. J., and Beagley, N.: Using an explicit emission tagging method in global modeling of source-receptor relationships for black carbon in the Arctic: variations, sources, and transport pathways, J. Geophys. Res.-Atmos., 119, 1288812909, https://doi.org/10.1002/2014JD022297, 2014.

Wang, Q., Jacob, D. J., Fisher, J. A., Mao, J., Leibensperger, E. M., Carouge, C. C., Le Sager, P., Kondo, Y., Jimenez, J. L., Cubison, M. J., and Doherty, S. J.: Sources of carbonaceous aerosols and deposited black carbon in the Arctic in winter-spring: implications for radiative forcing, Atmos. Chem. Phys., 11, 1245312473, https://doi.org/10.5194/acp-11-12453-2011, 2011.

Wang, Q., Jacob, D. J., Spackman, J. R., Perring, A. E., Schwarz, J. P., Moteki, N., Marais, E. A., Ge, C., Wang, J., and Barrett, S. R. H.: Global budget and radiative forcing of black carbon aerosol: constraints from pole-to-pole (HIPPO) observations across the Pacific, J. Geophys. Res. Atmos., 119, 195-206, https://doi.org/10.1002/2013JD020824, 2014b.
Warneke, C., Bahreini, R., Brioude, J., Brock, C. A., de Gouw, J. A., Fahey, D. W., Froyd, K. D., Holloway, J. S., Middlebrook, A., Miller, L., Montzka, S., Murphy, D. M., Peischl, J., Ryerson, T. B., Schwarz, J. P., Spackman, J. R., and Veres, P.: Biomass burning in Siberia and Kazakhstan as an important source for haze over the Alaskan Arctic in April 2008, Geophys. Res. Lett., 36, L02813, https://doi.org/10.1029/2008GL036194, 2009.

Winther, M., Christensen, J. H., Plejdrup, M. S., Ravn, E. S., Eriksson, Ó. F., and Kristensen, H. O.: Emission inventories for ships in the arctic based on satellite sampled AIS data, Atmos. Environ., 91, 1-14, https://doi.org/10.1016/j.atmosenv.2014.03.006, 2014.

Wiscombe, W. J. and Warren, S. G.: A model for the spectral albedo of snow, I: pure snow, J. Atmos. Sci., $\quad 37, \quad 2712-2733, \quad$ https://doi.org/10.1175/1520 0469(1980)037<2712:AMFTSA>2.0.CO;2, 1980.

Yttri, K. E., Lund Myhre, C., Eckhardt, S., Fiebig, M., Dye, C., Hirdman, D., Ström, J., Klimont, Z., and Stohl, A.: Quantifying black carbon from biomass burning by means of levoglucosan - a one-year time series at the Arctic observatory Zeppelin, Atmos. Chem. Phys., 14, 6427-6442, https://doi.org/10.5194/acp14-6427-2014, 2014.

Zarzycki, C. M. and Bond, T. C.: How much can the vertical distribution of black carbon affect its global direct radiative forcing?, Geophys. Res. Lett., 37, L20807, https://doi.org/10.1029/2010GL044555, 2010.

Zhang, L.: A size-segregated particle dry deposition scheme for an atmospheric aerosol module, Atmos. Environ., 35, 549-560, https://doi.org/10.1016/S1352-2310(00)00326-5, 2001.

Zhang, Q., Streets, D. G., Carmichael, G. R., He, K. B., Huo, H., Kannari, A., Klimont, Z., Park, I. S., Reddy, S., Fu, J. S., Chen, D., Duan, L., Lei, Y., Wang, L. T., and Yao, Z. L.: Asian emissions in 2006 for the NASA INTEX-B mission, Atmos. Chem. Phys., 9, 5131-5153, https://doi.org/10.5194/acp-9-5131-2009, 2009. 